Portland State University

PDXScholar

1989

\title{
Every man crying out : Elizabethan anti-Catholic pamphlets and the birth of English anti-Papism
}

Carol Ellen Wheeler

Portland State University

Follow this and additional works at: https://pdxscholar.library.pdx.edu/open_access_etds

Part of the European History Commons, and the History of Religion Commons Let us know how access to this document benefits you.

\section{Recommended Citation}

Wheeler, Carol Ellen, "Every man crying out : Elizabethan anti-Catholic pamphlets and the birth of English anti-Papism" (1989). Dissertations and Theses. Paper 3959.

https://doi.org/10.15760/etd.5845

This Thesis is brought to you for free and open access. It has been accepted for inclusion in Dissertations and Theses by an authorized administrator of PDXScholar. Please contact us if we can make this document more accessible: pdxscholar@pdx.edu. 
AN ABSTRACT OF THE THESIS of Carol Ellen Wheeler for the Master of Arts in History presented November 2, 1989.

Title: Every Man Crying Out: Elizabethan Anti-Catholic Pamphlets and the Birth of English Anti-Papism.

\section{APPROVED BY MEMBERS OF THE THESIS COMMITTEE:}

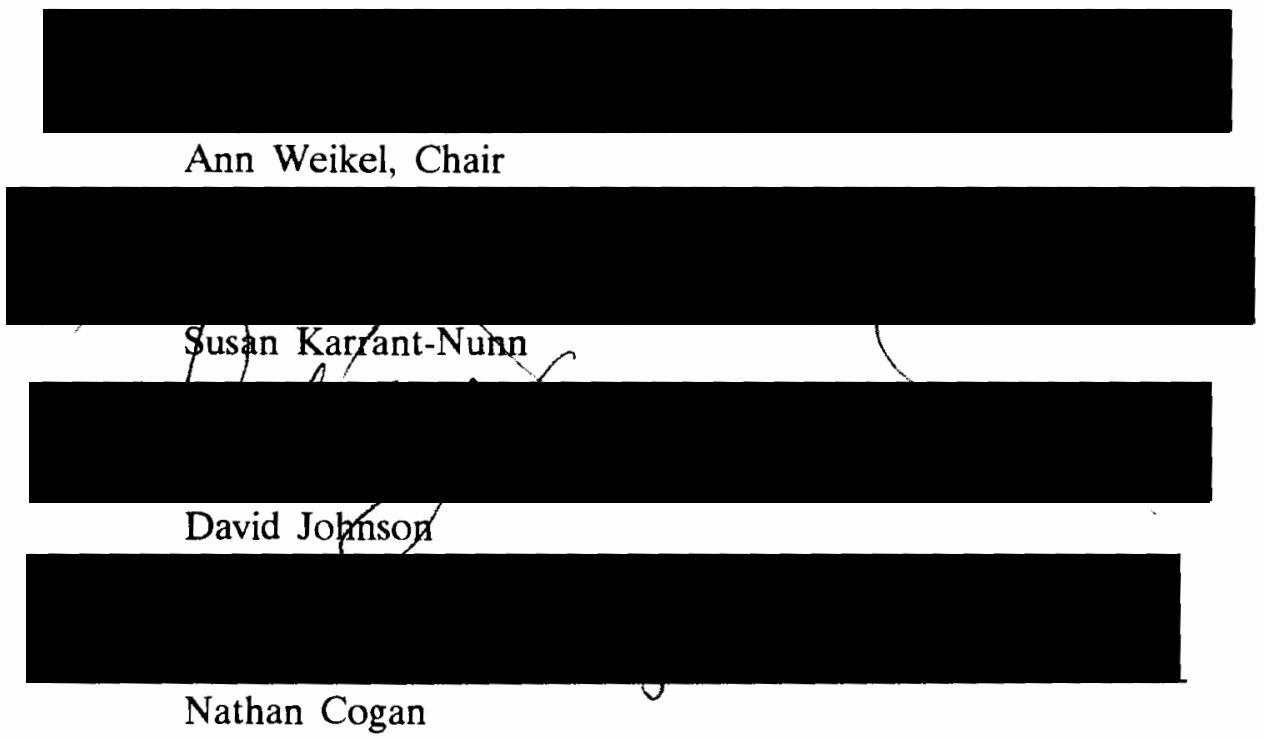

To the Englishmen of the sixteenth century the structure of the universe seemed clear and logical. God had created and ordered it in such a way that everyone and everything had a specific, permanent place which carried with it appropriate duties and responsibilities. Primary among these requirements was obedience to one's betters, up the Chain of Being, to God. Unity demanded uniformity; obedience held the 
universe together. Within this context, the excommunication of Elizabeth Tudor in 1570 both redefined and intensified the strain between the crown and the various religious groups in the realm. Catholics had become traitors, or at least potential traitors, with the stroke of a papal pen.

The printing press, which had come to England in 1467 , had become increasingly important as a tool to explain and, if possible, foster support for, crown opinion. Because of the regulatory system which had evolved since the introduction of print, it is possible to determine those pamphlets which were legal, and therefore either reflected attitudes officials wished to encourage, or were at least willing to allow. While the printing of pamphlets containing unacceptable views could not be stopped, the system was at least able to force them underground. Legal and illegal works vied to win readers to their side in the struggle for support; legal pamphlets present the governments definition and interpretation of the problems caused by the presence of the native Catholics.

These pamphlets are examples of what Richard Hofstadter has called "the paranoid style," as a literary rather than clinical description. The style is pervasive throughout the genre and is characterized by an over estimation of the enemy's power, and an almost obsessive concern with plots real and imagined. The anti-papist literature displays both the confidence that God stands with the Protestants and the fear of Catholic victory.

The aim of the pamphlets is, in the main, to warn of the danger presented by the Catholic presence, and to reinforce the crown's assertion that any anti-Catholic action is taken to prevent or punish treason. Examples of Catholic perfidy are rehearsed, and aims and methods explained with an almost hysterical determination. 
Having seen Mary's burning of Protestant heretics at Smithfield, the insistence that treason and not theology is the focus of concern is an attempt to convince the writer as well as the reader.

Even in those works which have a more political than theological agenda, however, attacks on papist theology appear. In the context of these pamphlets the attacks are not merely repetitions of the general Protestant assault on Catholic doctrine, but can be seen as an attempt to reassure themselves that, not only are Catholics not being persecuted for their religious beliefs, but they have no true religion for which to be persecuted.

The arguments, charges, and language of these pamphlets would continue to characterize the repression of Catholics, and the necessity for that repression, well into the nineteenth century--many charges surviving to the present day in virtually the same language. The anti-Catholic mind set developed between 1570 and the queen's death in 1603 became part of the English identity, and in certain quarters continues to define the Protestant/Catholic interaction. 


\title{
EVERY MAN CRYING OUT:
}

\section{ELIZABETHAN ANTI-CATHOLIC PAMPHLETS}

\section{AND THE BIRTH OF ENGLISH ANTI-PAPISM}

\author{
by
}

CAROL ELLEN WHEELER

A thesis submitted in partial fulfillment of the requirements for the degree of

\author{
MASTER OF ARTS \\ in \\ HISTORY
}

Portland State University

1989 
TO THE OFFICE OF GRADUATE STUDIES:

The members of the Committee approve the thesis of Carol Ellen Wheeler presented November 2, 1989.

Ann Weikel, Chair

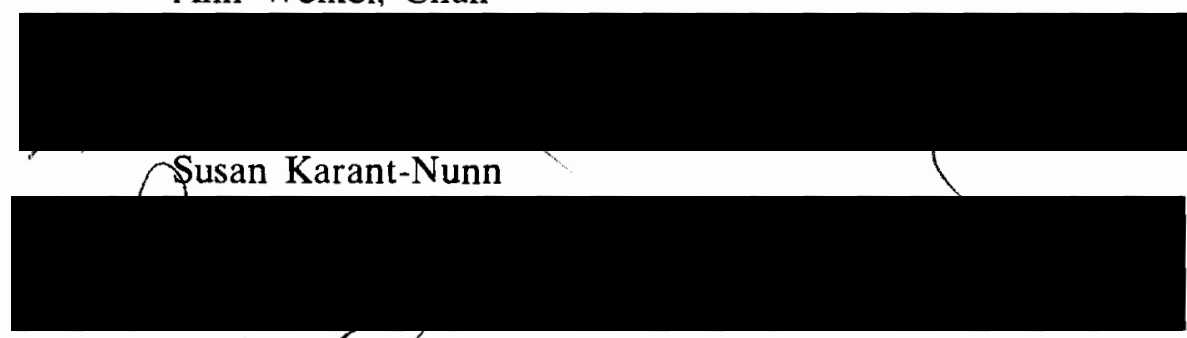

David Johnson

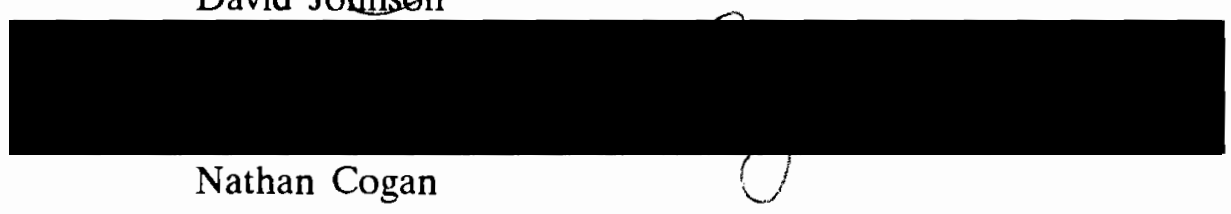

APPROVED:

Bernard Burke, Chair, Department of History

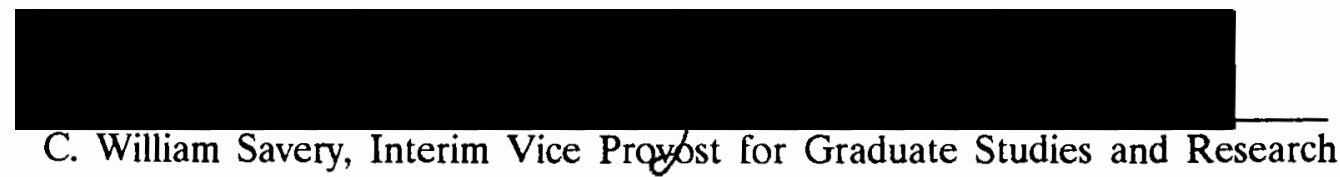


[T] heir misery is so lamentable (as we construe it), the perplexity which god hath driven them unto so terrible, that there is not a poor priest can enter to say mass but they imagine he bringeth their destruction. There cannot be a ship appear in any coast, not any prince's preparation for his own affairs, but it is for invasion of the realm. There can be no college founded to relieve men's banishments abroad, no entertainment given to any Catholic either in camp or court, but all is against the state; every man crying out: Quod venient Romani, et tollent locum et gentem nostram. ${ }^{1}$

William Cardinal Allen (1584) 


\section{THE EPISTLE DEDICATORY}

Many people have contributed to this thesis, through suggestion, encouragement, and hand-holding. My debts both academic and personal are many, and I wish to acknowledge some of them here.

First, I would like to thank Dr. Ann Weikel, my thesis adviser, and Dr. Susan Karant-Nunn, my graduate adviser, for their assistance and helpful advice during my undergraduate and graduate studies. The faculty and staff of the Portland State University History Department have always been willing to listen and aid in sorting out the many knots encountered by all students, and do so with a warm good humor which goes a long way toward easing the process.

My fellow students, Lynn Botelho and Dorothy Rackley, have been willing to read the various drafts of this work and make sensible suggestions, for which I am most grateful.

Fr. Barry Hagan, C.S.C., Archivist of the University of Portland, and his secretary, Martha Wachsmuth, have rendered invaluable help in finding information on aspects of English Catholic Recusant life. Fr. Hagan's broad bibliographical knowledge proved most helpful in seeking out documentation and information.

To my parents I am indebted for the incalculable aid of all types, especially emotional, which has made it possible for me to continue my studies.

Finally, to the memory of my grandfather, John H. Burton, who taught me the value of learning, and encouraged my hunger to know, this work is dedicated. 


\section{ABBREVIATIONS}

STC: A Short Title Catalogue of Books ... edited by A. W. Pollard and G. R. Redgrave, 2nd Edition (edited by Jackson, Ferguson, and Pantzer). London: The Bibliographical Society, 1986.

EEBr: Early English Books (reel number), microfilm copies of STC titles. Ann Arbor: University Microfilms.

Hughes and Fries: Crown and Parliament in Tudor--Stuart England. P. L. Hughes and R. F. Fries, editors. New York: G. P. Putnam's Sons, 1959.

Hughes and Larkin: Tudor Royal Proclamations. P. L. Hughes and L. F. Larkin, editors. New Haven and London: Yale University Press, 1969.

Arber: A Transcript of the Registers of the Company of Stationers of London. Edward Arber, editor. New York: Peter Smith, 1950; reprint of 1875 edition.

DNB: The Dictionary of National Biography.

OED: The Oxford English Dictionary. First Compact Edition.

Alison and Rogers: A Catalogue of Catholic Books in English, ... 1558-1640. A. F. Alison and D. M. Rogers, editors. London: Wm. Dawson \& Sons Ltd., 1968, reprint. 
TABLE OF CONTENTS

PAGE

DEDICATORY EPISTLE $\ldots \ldots \ldots \ldots \ldots \ldots \ldots \ldots \ldots \ldots \ldots$ ii ABBREVIATIONS $\ldots \ldots \ldots \ldots \ldots \ldots \ldots \ldots \ldots \ldots \ldots \ldots \ldots \ldots \ldots$ iv

AN INTRODUCTORY EPISTLE TO THE READER $\ldots \ldots \ldots \ldots \ldots \ldots$ vi

CHAPTER

I BY WORDS OR WRITING, OR BY CRAFT $\ldots \ldots \ldots 1$

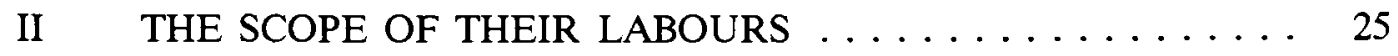

III ROGUISH PEDLARS OF WHORISH MERCHANDICE . . . . 52

IV CONCLUSION: NO INNOCENT WAS TORMENTED $\ldots \ldots 66$

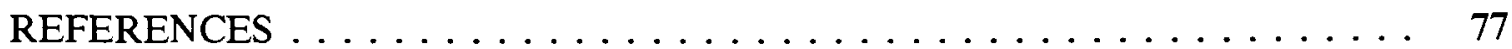

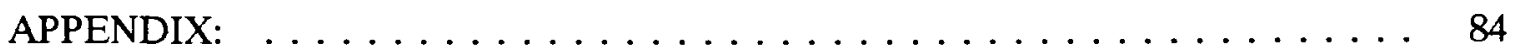




\section{AN INTRODUCTORY EPISTLE TO THE READER}

And if nothing else will deface you, yet printing only will subvert your doings, do what ye can, which the Lord only hath set up for your desolation.

--John Foxe $e^{2}$

To modern ears, John Foxe's assertions of the ability of the press to eliminate contrary opinion (and those who maintain it), seems at best overstated. If we are no longer certain that the printed word possesses such powers, neither are we as certain about the nature of "truth," and who, if anyone, holds it. For the Elizabethans, the problem was not who held truth, but how to deal with those who clung with such obstinacy to error--and the threat they presented to the nation's place in the Godly order of the cosmos.

The pulpit had been, and of course remained, an important fortress against the onslaught of the forces of evil, but the printing press had begun to offer a battery from which to fire upon the foe. Protestant exiles from Marian England had shown an increasing understanding of the uses to which the magic of printing might be turned. ${ }^{3}$ The extent of their lessons became evident in the writings of the subsequent reign.

With Elizabeth's excommunication in 1570, the full force of legal, moral, and religious rhetoric was turned against the Catholics, both native and foreign. Their devilish plots, real and (quite often) imagined, were increasingly offered for the edification and horror of the English public. The outwardly innocent follower of the "old religion" was unmasked to show the sinister papist intent upon the destruction of Protestant England, the death of the Queen, and the enslavement of those Englishmen 
who had not been killed outright. Invective flowed from the pens of many sorts of men, from crown officers to Puritans awaiting justice in the Tower. Brief pamphlets, impressive tomes, and broadsides were written, approved, and published in what seems an endless stream, and to real effect.

Carol Wiener has proposed that by the end of Elizabeth's reign, an Englishman's self-identity included an anti-papal stance. ${ }^{4}$ I believe that this identification (and especially its vehemence) was a development of the period from 1570 to 1603 , and is reflected in, if not a product of, these pamphlets. ${ }^{5}$ Anti-papal sentiment was, of course, not a new phenomenon in England, but the native anti-papal sentiment was no longer just an expression of the desire for native clerics and royal independence from Rome's dictates. Henry VIII had used the English distrust of foreigners, and the growing sense of national identity to support his break with Rome in his desperation for an heir.

The reign of Mary Tudor, and especially her marriage to Phillip of Spain, firmly tied Roman Catholicism and foreign domination together in the minds of Englishmen. The heresy executions at Smithfield, made infamous by Foxe, did little more than confirm many Protestants in their resistance and make Catholicism an anathema in the minds of the radical Protestants.

While the religious settlement of Elizabeth's reign proved to be rather conservative, it assured institutional Protestantism, for the lifetime of the monarch at least. Elizabeth's near death from small pox in 1562 intensified the concerns for the future of the nation. The Queen's reluctance to name a successor, both before and after her illness, left only one potential heir: the Catholic, Mary Stewart. The potential for the Guise Queen of Scotland, the former Queen of France, to gain the 
English throne encouraged the Catholic hopes for the future, and terrified the Protestants who had returned to power.

The Northern Rebellion in November 1569, in which both Northumberland and Westmoreland were implicated, not only raised the fears of a general Catholic uprising, but was to become linked (after the fact), with the bull of excommunication promulgated in February 1570. The perception of a papist threat now seemed to grow into a struggle for the survival of the nation. It is within this context that the pamphlets discussed here were published. Legally printed pamphlets constitute an official effort to respond to the perceived threat of Catholic treason and to the accusations of religious persecution made by the Catholic English. These writings had a lasting impact on English society and culture, making an institution of antiCatholicism for centuries thereafter.

Chapter I concentrates upon the mechanics and regulation of printing in sixteenth century England, both within the context of the desire for order, and an attempt to gain some idea of popular demand-if not popular opinion. It is difficult, if not impossible, to chart the flow of anti-Catholic opinion. While there are pamphlets that are known to have come from crown sources, either to explain the situation in England or to direct opinion, there are also instances of works written for a popular demand, driven by the desire for financial profit. Whether the bulk of anti-Catholic rhetoric flowed down from the crown, bubbled up from the people, or came from all classes cannot be answered here. A closer study, made from sources unavailable at Portland State might offer some important answers. It is certain that a wealth of useful material is yet to be mined from the Short Title Catalogue and related sources. 
Chapter II examines the queen's Excommunication, its impact on English Catholics, and the questions it raised about their loyalty to the crown. Chapter III is concerned with the question of "religion," the efforts to separate "Popery" from "true" Christianity, and the casting of Catholicism as a purely secular entity at best, a manifestation of evil at worst.

The works I have examined are all in English, since I am trying to present an impression of the general mind set of Englishmen. While literacy and distribution remain problematic, by concentrating on vernacular texts there is greater chance of their broad distribution, and readership. Many works which for various reasons had been originally written in Latin were "Englished" for this very reason, as well as works first appearing in Continental vernaculars. I have focused on "secular" pamphlets, that is works more concerned with questions of the social/political order, although Chapter III does turn to more theological questions. Since the Anglican response is, at least ostensibly, one directed to the question of loyalty, these pamphlets seemed a better sample. We shall see, however, that the cloak of secular concerns covers many other agenda.

While the effect of John Foxe's Acts and Monuments can hardly be overestimated, I have purposefully focused on its lesser known, if more abundant, siblings. It would be impossible to deal with the impact of Foxe within the confines of this paper, and examine the body of anti-Catholic literature, without doing a grave injustice to both. There exist many excellent studies of Foxe presently available for examination, and there is the additional concern that the many editions of the book which not only ante-date and post-date the period considered here (1570-1603), but are in themselves almost a genre. The reader is directed toward this body of scholarship, 
especially the work of William Haller, to gain the fuller picture of the ways in which Foxe continued to focus the anti-papist stance for the English.

Whenever possible I have used microfilm copies of the pamphlets. I have retained original punctuation and spelling, although use of $i, j$, u, and $v$, has been altered to conform with modern practice. In the case of contractions, I have provided the missing letter for clarity. When the quote is from a secondary source, any elisions or alterations will be identified as to the editorial hand at work. Primary and secondary sources are listed separately in the list of references.

Dates will appear as given on the title page of the pamphlet (unless otherwise noted). There was no single practice for dating among printers of the period; however, since I do not intend to focus on the response to any single incident within the specified period, this fact is not critical to my case.

These pamphlets are a hardy group of survivors. We must recognize that many of their fellows exist (as far as we know), only as titles in a stationer's register, or a reference in a surviving work. At best we must be like archaeologists, fitting together the remaining fragments in hopes of reconstructing some model of an earlier world. We do so with the realization that the politics of religion has its roots in that cosmos which is not ours. It is a universe whose rules, realities, and goals--though gone--continue to echo in our own. 


\section{NOTES:}

\section{INTRODUCTION}

${ }^{1}$ William Allen, Defense of English Catholics (Ithica: Cornell UP, 1965), p. 236. 1584 edition, edited by Kingdon. The text is John 11:48, the Latin is given in the Revised Standard Bible's translation as: "The Romans shall come, and take away our place and our nation."

2 John Foxe, The Acts and Monuments of John Foxe (London: R. B. Seeley and W. Burnside, 1841), Vol. 1, p. 512, from a preface addressed to Catholics included in the 1563 edition.

3 Jennifer Loach has argued that the Marian response to these efforts, especially their own use of printed works, has been greatly underestimated in past studies. See her article, "The Marian Establishment and the Printing Press," in the English Historical Review, Vol. 101 (January 1986), pp. 135-148.

4 Carol Z. Wiener, "The Beleaguered Isle," Past and Present, Vol. 51 (May 1971), p. 27. Wiener feels that "It would be impossible to say" when the change occurred, I think it is clear, as I will argue below.

${ }^{5}$ I will use the term "pamphlet" in a very general sense for all these works, regardless of length. The point at which a pamphlet "becomes" a book is quite unclear, and unimportant, for my purposes.

${ }^{6}$ William Haller, The Elect Nation (New York: Harper \& Row, Publishers, 


\section{CHAPTER I}

\section{BY WORDS OR WRITING, OR BY CRAFT ${ }^{l}$}

Order is ye mother and preserver of things: for sure it is that the society of man consisteth in ruling and obeying: obedience is the virtue that theacheth all their duty to god and man. ${ }^{2}$

None ought to rule, except he first have learned to obey. ${ }^{3}$

The sixteenth century inhabited a different cosmos, a universe which not only produced its own music, but danced. ${ }^{4}$ In spite of the efforts toward rearranging the pieces by various astronomers, for most people (if they thought of it at all), the function and configuration of the cosmos was much as it had been for the ancient Greeks. Plotinus's meshing of Plato and Aristotle--Neoplatonism--as filtered through, and adapted by, early Christian thought, had become by the Tudor era not merely a model, but the accepted reality. That reality was conceived as the Chain of Being, whose links descended from God, which had a place for all manner of people and things. It was an order ordained and, at least in theory, immutable.

This Godly order, framed by divine law, was reflected in the microcosm of the kingdom, which in parallel with the heavenly kingdom above, was sustained and held together by civil and ecclesiastical law.

[O]f law there can be no less acknowledged then that her seat is the bosom of God, her voice the harmony of the world: all things in heaven and earth do her homage, the very least as feeling her care and the greatest not exempted from her power; both angels and men and creatures 
of what condition soever, though each in different sort and manner yet all with uniform consent, admiring her as the mother of their peace and joy. ${ }^{5}$

Law breaking was, therefore, not only a threat to local peace and stability, but by parallel, and extension, to national order and divine order. The twentieth century thinks in terms of law and order, the sixteenth of law as order.

Part of the transition from the medieval world to the "modern" was an expansion of the mechanisms of law (such as the addition of the Star Chamber under Henry VII), in order to establish formal structures which would displace the physical solutions to problems. From the Assizes (Court of King's Bench), attempts to deal with local crimes to the innumerable lawsuits over property rights and uses to the Court of Requests (legal remedy for the poor), to the Court of Wards for cases of wardships, Chancery Court for "equity," the aim was to provide a system whose various parts would mesh to solve the problems which arose from the contact between as yet imperfect man and his neighbors. From the local Justice of the Peace, to the King (or Queen) and the Council, all eyes watched for disharmony and sought to string the cords of society back into their proper order as quickly as possible.

It was not only the danger presented by physical violence, or outright challenges to law which was feared. Order depended not merely on physical obedience of the people, but their mental behavior as well. Seditious talk could be as dangerous as seditious action; rumor was a threat great enough to prompt officials to trace it to its source, or at least try. ${ }^{6}$ Whether at home or in a foreign land, an Englishman was expected to behave in a loyal and obedient fashion, both in thought and deed. To insure that they did so, the crown was well advised to keep an eye on its subjects: 
to have certain officers to pry abroad, and to observe such as do not live and behave themselves in a fit sort agreeable to the present state, but desire rather to be under some other form or kind of government. ${ }^{7}$

The price of order was vigilance. Threats to order must be stamped out, or best of all prevented, by good law and good magistrates. When law had proved itself insufficient, and magistrates unable to cope, the answer was clearly more and stronger laws. All Elizabethan Parliaments "contained a high proportion of J.P.'s"; ${ }^{8}$ that is the men passing these laws were the very ones expected to enforce them at the local level. Obsession with the outward displays of order was a manifestation of the very real concern for the survival of the nation. To maintain the world in which they functioned, laws must occasionally intrude upon private lives, however reluctantly. It is within this framework that "speech" signifies both the actual verbalization by an individual, and other types of utterance--including print. While there were separate statutes and proclamations on "rumor" and printing, many such pronouncements lumped the two together under the broader concept of "publishing." $"$ In effect, there was no difference between Print and speech when it came to enforcing order.

The press, like all new technology, was beginning to show that it was not quite as simple as it had appeared to be in the beginning. A faster and easier mode of duplicating than the pen, it also provided a method for differing opinions to be put forth to those who could read, or had someone to read to them. This could be a boon to the state; complete texts of public acts, for example, were published until 1576, and collections of these served as reference works. ${ }^{10}$ However, the base nature of man meant that not all such publications in print were of a proper sort. Too often an author had a peculiar view of the world and how it should be run, and insisted upon 
sharing his ideas. It was then necessary for law to step in and remedy the lapse in obedience and judgment. From the time of Caxton's first book (1467), the crown and its minions were playing a perpetual game of "catch-up" in an attempt to tame the press and make it a compliant servant.

In law, the crown's right to regulate printing rested on three points:

1. That printing was first introduced into England at the behest of the king, who therefore held the original right to exercise the craft.

2. That the stability of government and the peace of the realm demanded strict control. (And)

3. That such regulation had in fact been exercised by the crown ever since the introduction of the first English press in $1467 . .^{11}$

Early regulation had aimed at stopping heretical books, and limiting foreigners engaged in printing. ${ }^{12} 1538$ saw the beginnings of the formal structure which, gradually augmented and strengthened, would struggle to control the authors, publishers, and printers, throughout the Tudor period, and beyond. The Star Chamber decree of 16 November 1538 forbade the publishing of English language books "onles upon examination made by some of his gracis privie counsayle, or other suche as his highnes shall appoynt."13 The monarch's Privy Council's place in the regulating system was to remain constant, even as more authorities were added to the list of regulators.

In a sense, the scope of laws attempting to regulate rumors and printed works may be seen as a record of failure. The necessity of new laws, or the perception of that necessity, speaks to this failure. ${ }^{14}$ With little variation, these many acts thundered against the "cankered and traitorous hearts"15 of "light and seditious persons," 16 which would "obstinately or maliciously attribute"17 "lewd and light tales told, whispered, and secretly spread abroad," ${ }^{18}$ or "false fond books, ballads, rhymes and other lewd 
treatises, ${ }^{19}$ such persons acting "contrary to their bounden duty of allegiance and contrary to all good order" 20 were striving "by all possible means they could devise to compass the destruction of [his/her] majesty and the utter ruin and overthrow of this state and commonweal"; 21 "such great enormyties and abuses"22 could at best earn his/her "Majesties greevous indignation, ${ }^{23}$ at worst loss of goods, and perhaps life. ${ }^{24}$ This language highlights the sense of danger which haunts not only the English presses, but all actions or ideas out of the norm. The intent of the crown and its officers was to direct this flow of opinion into an acceptable channel straight and high-banked. The Elizabethan Privy Councillor's oath was clear on this point:

You shall not know or understand of any manner of thing to be attempted, done or spoken against her Majesty's person, honour, crown or dignity royal, but you shall let and withstand the same to the uttermost of your power, and either do or cause it to be forthwith revealed either to her Majesty's self or to the rest of her Privy Council. ${ }^{25}$

The monarch and the Privy Council bore the bulk of the responsibility for press regulation until the Company of Stationers received the royal charter in 1557.

A brief review of the history of printing, and printers, in England will be helpful to the understanding of the role of the Company in the regulation of printing. The term stationer derives from the years before the press. The prospective book buyer would go to a market or fair, and find the stall of the merchant who would take his order for a book. This man, remaining in one place, came to be called a "stationer." It was the stationer who sought out the craftsmen necessary to produce the book required by the patron. As early as 1371 scriveners, limners, bookbinders, and stationers had formed a guild. Over the years, the scriveners and those specializing in legal work had dropped out, and printers gathered in. ${ }^{26}$ 
Printing first came to London in 1480 with the press of Lettou, who had brought his type from Rome, and produced two books in Latin. ${ }^{27}$ By 1500 , there were 5 printers in the City, about 33 by $1523 .^{28}$. A royal charter for the guild was requested in 1542 , but not granted until $1557 .^{29}$ When it was at last granted, the charter was couched in regulatory terms:

Know that we, considering and manifestly perceiving that certain seditious and heretical books rhymes and treatises are daily published and printed by divers scandalous malicious scismatical and heretical persons, not only moving our subjects and lieges to sedition and disobedience against us, our crown and dignity, but also to renew and move very great and detestable heresies against the faith and sound doctrine of Holy Mother Church, and wishing to provide a suitable remedy in this behaf [do grant this charter]. ${ }^{30}$

If the charter was intended to provide relief from seditious books, the result did not meet crown expectations and, in June of 1558 , martial law was added to the tools turned against these evil writings. 31

While it was not as immediately effective as the crown might have wished, the linking of the men who printed and sold the books to their regulation was a shrewd action. As Handover points out, the forming of a single, formal organization for printers and booksellers worked to everyone's advantage. ${ }^{32}$ Both groups had an interest in limiting the number of presses and printers in the country: the government to restrict the access of writers to publication in print, and the stationers to protect their economic interest. Between 1500 and 1510 , printing became increasingly concentrated in the city, and London would remain the focal point for the trade in England. $^{33}$ This meant that, at least on paper, English stationers would be confined to one area, and desirous of policing themselves: "in effect printing and bookselling in England was controlled by the hundred odd men who made up the Stationer's Company at the time of its incorporation. ${ }^{34}$ 
If the laws and regulations could not stem the flow of questionable pamphlets and books, the incorporation of the Stationers put the battle on clearer footing. The line which divided legal from illegal printed works had been made much sharper, and its crossing increasingly difficult and hazardous. If the laws could not achieve their goal of absolute control, at least their violation required much more effort and expense than many could, or would, be willing to face. Only those who felt a very strong justification would wish to chance failure.

Elizabeth's accession in November of 1558 did not have a profound effect upon the battles over speech: the field remained the same, the shift was in the side from which the royal standard flew. McGrath had accurately called the period between the last Tudor's accession and her excommunication from the Roman church "The Years of Uncertainty. ${ }^{\text {35 }}$ Puritans hoped for a return to an Edwardian settlement; some Catholics hoped to save the nation from Protestantism, or at least return to the Papal fold quickly, and in their enthusiasm they misread the attitude of the nation.

Consider the present state of England, which is newly returned to schism and heresy by the will of the new queen and against the feelings of many of the principle men of that kingdom and the major part of the people, who desire the Catholic religion and union with the church. ${ }^{36}$

If the religious settlement was as yet unclear, the crown's expectations for the behavior of its subjects was as constant as it had been under any Tudor. To "utter by open preaching express words or sayings," or "by any writing, printing, overt deed or act," the suggestion that the queen had no right to the throne, was still treason. ${ }^{37}$ The Commission of 1559 was given the power to examine (with the aid of a jury and witnesses): 
heretical opinions, seditious books, contempts, conspiracies, false shewings, published, invented, or set forth, or hereafter to be published, invented or set forth by any person or persons against us or contrary or against any the laws or statutes of this our realm. ${ }^{38}$

If the crown was disinclined to look into men's hearts, it was as concerned as ever with their bodies and mouths.

While the 1557 charter of the Stationers' Company had been a first step toward linking the printers to the crown's efforts to enforcement of laws regulating the trade. The year 1566 saw the second. The Star Chamber decree of that year (29 June) confirms that the Company (more specifically the wardens) was at the center of the regulatory system. ${ }^{39}$ Paragraph One forbade the printing or importation of books which violated any law, present or future, little more than a repetition of previous ordinances.

Paragraph Two orders that offenders:

shall not onelie forfait all such Bookes and Copies, as shall be so printed or brought in; but also shall from thenceforth never use or exercise, nor take benefit by anie using or exercising of the feate of printing, and shall susteine three moneths imprisonment, without balie or mainprise. ${ }^{40}$

Also forfeit was the bond now required of those in the trade. ${ }^{41}$ The offending books were to be destroyed "or made waste paper," at the discretion of the Master and Wardens. The right of the Company to search the cargo of incoming foreign ships for such contraband, and the power to search any suspicious place in the realm which might store or produce such works was granted, augmenting the right to search granted in the charter. The High Commission was given the duty to set the amount of the bonds, "reasonable summes of money." Three years later another act, banning seditious books from abroad, referred to the "mylde example" the Star Chamber made of those who violated these goodly laws. ${ }^{42}$ 
Between 1560 and 1586, there were over a dozen acts which concerned themselves in whole or in part with the regulation or printing and publication. ${ }^{43}$ Most were general, some dealt with specific publications, such as the Bull of Excommunication (1570), and the Admonition to the Parliament (1573).

The Company of Stationers itself was hardly the model of regulatory efficiency. At least a third of extant books do not appear on the pages of the Company's register. ${ }^{44}$ Although the term "copyright" does not come into usage until at least 1767 (in Blackwell), the use of "copy" in at least a general sense of copyright appears in 1577 in the registers. ${ }^{45}$ This was not, of course, quite the same legal right under which the copyright functions today. There was no international convention to protect those rights in other countries, which meant that foreign works could be translated and printed without any consideration for the original author. ${ }^{46}$ Elizabethan copies were held as a right of use granted by the crown; if so permitted in the grant, copies could be sold, temporarily reassigned, or left to one's heirs; others ended with the holder's death, or after a set period of time. In theory, this kept the right to print, for example, all Bibles and Testaments (held by John Jugge); psalters, primers, and prayer books (William Seres); or music and lined paper (composer William Byrd); and other categories, for that man and his assignees, exclusively. ${ }^{47}$ It also meant that the most profitable types of books were kept from the majority of printers, the most renumerative copies held by a handful of men. ${ }^{48}$

Without a lucrative copy, the expense and effort of running a printing shop must have been a heavy burden indeed. The minimum requirements for an establishment would be: a space for a shop (usually not large, but keeping in mind that the press could be six feet tall--or more); the press itself; enough type for at least 
one page; printer's ink; and paper. Plant estimates that an "ordinary" shop of the sixteenth and seventeenth century would require about $\$ 150$ worth of equipment. ${ }^{49}$ Printers most likely made their own ink, which was $\mathrm{m}$ ore like paint than writing ink, and could bleed through to the other side of the paper. The formula required one pound of a varnish of linseed oil and juniper gum, combined with one ounce of smokeblack, and boiled for a considerable period of time. There is evidence of ink being sold in Oxford in 1549 , at a cost of 2 s per half pound. ${ }^{50}$ Paper for the most part, came from the Continent, imported from the Low Countries and France, classified by 1563 as a necessary import. In $1570,1,728$ reams were imported at a value of $£ 403$, and paid a customs duty of $£ 10,6 s, 2 p .^{51}$ Costs for paper continued to rise over the century: 1511-20--2s, $4 p$ per ream (.35p per sheet); $1571-82--4 s, 9.5 p$ per ream, now a 12 rather than a 20 quire ream (1.19p per sheet). ${ }^{52}$ Paper was often paid for by giving the merchant copies of the finished book..$^{53}$

Having got a press, secured paper, and made one's ink, the printer had but one component missing, the hardest to acquire: type. The shortage of type remained constant throughout the century, and shortages in some specialized fonts continued into the eighteenth century. ${ }^{54}$ While it was common to print one page at a time, ${ }^{55}$ a single folio page could require three to five thousand letters, ${ }^{56}$ an efficient shop, if possible, would try to compose the second page while the first was being printed. Like paper, most type was imported. Although there were some type founders in England in Elizabeth's time, there is "no evidence" of their making either Roman or italic type. 57 Importation of Dutch fonts was common until they were banned in $1720 .^{58}$ The shortage of copper, necessary in the making of matrices to cast the type, was probably a factor. However, in 1570, the printer, John Day (with aid from Archbishop Parker), 
was able to cast a font of "Italian letter" for 40 marks. ${ }^{59}$ It is little wonder that the Company had the sense to keep the type seized from illegal presses, and to "rent" it out to printers. ${ }^{60}$ The lead based type would require a strong arm, and be very difficult to move without a wagon, considering that the weight of the type for a folio page was nearly a hundred pounds. ${ }^{61}$

The output of a printing shop would depend on the number of presses, type, and workers. While John Wolfe was able to produce 20 works in 1589 (a record for this period), most shops, with only one press, might produce as few as two works, or less. $^{62}$ With only one press, one might do well to produce only one sheet (both sides) per day. A 1523 contract between Richard Pynson the elder (printer to Henry VIII), and John Palsgrave stipulated the production of one sheet per day; the Bodleian Catalogue (1604), was also printed at that speed. ${ }^{63}$

The choice of what to print, while ideological considerations could enter into the calculations, might come down to the simple problem of economic necessity, or desire. In an exasperated tone, the Royal Injunctions of 1559 complained that there was "great abuse in the printers of books, which for covetousness chiefly regard not what they print so they may have gain." ${ }^{\text {"64 }}$ One primary case is that of the infamous John Wolfe. Wolfe was a member of the Fishmonger's guild, but had apprenticed with Day, and worked in Florence before setting up shop in London. ${ }^{65}$ The nice settlement of printing in the realm now found itself faced with a man who claimed that he intended to reform the practice of printing "just as Luther reformed religion. ${ }^{166}$ Wolfe set up his press in 1581, and by Easter was having trouble with Barker over copyrights. By May of the next year, he had three working presses, and two years later was printing Italian language books, primarily drawn from the papal Index. ${ }^{67}$ By April of 
1587, the Company of Stationers had found a solution to their problems with the Luther of print; he was translated into the company and made substitute Beadle--that is put in charge of shutting down the sort of presses he had been running for the past six years. ${ }^{68}$ Some lesser copies were fobbed off on the more rebellious printers of the Company, the larger and more lucrative copies remained in the hands of the same powerful printers, and their "Luther" enforced the status quo ante. The rumblings within the Company had been quieted, but Wolfe's example was not lost on others outside the sanctioned guild.

Indeed the advent of illegal presses, which were to trouble the crown so, "coincided with John Wolfe's rebellion against the privileged printers." ${ }^{69}$ The presses hidden in England, as well as the Catholic presses on the Continent, although perhaps encouraged by Wolfe's success, were driven by an inner force. The so-called Greenstreet House Press was a product not necessarily of the new sense of printer's rebellion, but of the Jesuit mission's arrival in England. ${ }^{70}$ William Carter (who had apprenticed with Mary's official printer, John Cawood) had been producing illegal books in the year before Wolfe's arrival on the scene (1579). Allison and Rogers list at least 250 Catholic books published in England between 1558 and $1603 .^{71}$ Carter himself put out about 12 works before his arrest at the end of 1579. Although he had been "dyvers tymes before in prison for printing of lewd pamphlets," he was released. ${ }^{72}$ Carter returned to his work, Printing Parson's A Brief Censure (1581)--a copy of which was found on the doorstep of London's City Recorder, William Fleetwood. ${ }^{73}$ Fleetwood, however, was at last able to track down the naughty printer in April 1582: 
It fell owt that in the first wike of Lent there was a booke cast abrood in commendinge of Campion and of his fellows and of theire deathe. I pursued the matter so nere that I found the presse, the letters, and the figures and a nosmber [sic] of the bookes. ${ }^{74}$

Carter was executed on 11 January 1584 , ostensibly for a particular passage, considered treasonous, in Martin's Treatise of Schisme, having admitted to printing 1,250 copies of the pamphlet. ${ }^{75}$ Puritans, too, set up illegal presses, the one which printed the Marprelate tracts is the best known. ${ }^{76}$

In this period, the number of legal presses continued to grow as well. In December 1582, Christopher Barker reported to William Cecil:

There are 22. printing howses in London, where. 8. or 10. at the most suffise for all England, yea and Scotland too. but if no man were allowed to be a Master Printer, but such whose behavior were well knowne, and auctorised by a warrant from her Majestie, the arte would be most excellently executed in England, an many frivolous and unfruitfull Copies kepte back, which are dayly thrust oute in prynt, greatly corrupting the youth, and prejudicall to the Comon wealth manye wayes. [sic]. ${ }^{77}$

The fact that Mr. Barker had five presses and held the lucrative position of printer to the queen, must certainly have meant that he was the right sort to be a Master Printer. In the following year, a census conducted by Barker and Francis Coldock counted 23 printers and 53 presses in London, of which Barker and Wolfe had five each, Day and Denham both had four. ${ }^{78}$ The Stationers were victims of their own success. With so much competition, the pressure on smaller houses to survive must have been strong, and the assertions of legal pronouncements that printers were putting out dubious works only for gain certainly had at least an element of truth.

It is of little surprise, then, that the Stationers' Company was consulted over the regulations issued by the Star Chamber in $1586 .{ }^{79}$ Dated 23 June, the decree laments that there were now "suche greate enormyties and abuses as of late, more then 
in tyme paste," and that previous laws were "to lighte and small for the correctyon and punishment of soe greivous haynous offences.." ${ }^{80}$ The Archbishop of Canterbury was named as the primary officer to enforce the new regulations, along with the Privy Council. The ordinances tightened up the methods of regulation, and reconfirmed the place of the Company of Stationers' in the system. Printers were given ten days from the date of the decree to present certification of the legality of their presses, and a ten day grace period was given for all new presses, set up subsequent to the act, to gain such certification. ${ }^{81}$ Legal presses were now restricted to the City and suburbs of London, except for one press each at Cambridge and Oxford. The Company was again empowered to search premises without the owner's resistance, and violators would have their presses smashed, serve a year imprisonment, and be prohibited from owning a press or becoming a Master--but could work as journeymen. ${ }^{82}$

Paragraph Three dealt with the excess of printers and presses by restricting the number to that of the previous six months, until that vague period when:

the excessive multytude of Prynters having presses already sett up, be abated, dyminished, and by death gyving over, or otherwyse brought to so small a number of maisters of owners of prynting houses of abylity and good behavyour [is reached]. ${ }^{83}$

At such time the Company would be allowed to nominate men to be presented for crown approval to fill the openings as they arose. Violation carried the same year's imprisonment, but the queen's printer was exempted from the regulation.

Prior approval of all printed matter was to be obtained from the Archbishop, the Bishop of London, or a Privy Council member (the queen's printer again exempted), defacement of his presses, banishment from the trade, and imprisonment were the penalties. ${ }^{84}$ 
Paragraph Six confirmed the charter right of the Company to search, seizure, and destruction of the offending presses. Discovered materials were to be presented to the Ecclesiastical Commissioners, the Archbishop of Bishop of London, "for the tyme beinge to be one" of the three required. ${ }^{85}$

Paragraph Seven directed the Company to destroy all presses, type, and other instruments, and to return the remains to the former owners within three months. ${ }^{86}$ We have noted above, however, that print found its way into the custody of the Company, common sense and the type shortage winning out over regulation.

The Eighth ordinance, in the interests of limiting the number of men in the trade, restricted the Master and Upper Wardens of the Stationer to three apprentices; the Under Wardens and men of the Livery to two; the Yeomenry of the guild to one apprentice (if the printer was not a journeyman); the queen's printer was allowed six apprentices. ${ }^{87}$

The final paragraph restricted the Oxford and Cambridge printers to one apprentice, but did allow them to make use of the "helpe of any Journeyman being freeman of the cyttye of London. ${ }^{188}$ The weight of responsibility for regulation, especially the review of proposed publications, weighed so heavily on the Archbishop of Canterbury, that two years later twelve other clergymen were appointed as "correctors of the press" by Whitgift. ${ }^{89}$

While the crown was fighting the excesses of the printer's art, certain of its officers were discovering the usefulness of such works, or at least the appearance of the pamphlets questionable legality. The primary vehicle of governmental opinion was the proclamation, at least for the first decade of Elizabeth's reign..$^{90}$ Of the nearly 450 Elizabethan proclamations which survive, over a dozen have drafts in the hand of 
William Cecil. ${ }^{91}$ Although there is no proof in the form of other surviving drafts, it would seem safe to assume that Cecil's hand guided many more than that small group of publications into being. For example, Cecil did order Jewel to write his defense of Anglicanism, ${ }^{92}$ and probably encouraged Jewel's reply to the Bull of Excommunication. ${ }^{93}$

More significant for our consideration is the involvement of crown officers in "surreptitious" printing. The title page of a pamphlet can be informative not only in what it displays for the reader, but for what it omits as well. The omission of information may not always have a political significance, for example, those volumes which were privately printed for personal consumption or circulation among friends. ${ }^{94}$ Omission of portions, or all, of the usual information: author, place of publication, printer's name, or a false imprint occur where these elements need to be kept secret to protect the safety of one or all of those people, especially if the work is illegal, such as those products of Catholic presses. Woodfield classifies these as "secret" as opposed to "surreptitious" pamphlets. ${ }^{95}$ A book can be considered surreptitious if:

A. It has a fictitious printer's name imprint and no location or a false location;

B. It has no printer's name or imprint and no location or a false location;

C. It has the actual printer's name completely translated and no location or a false location.

It is important to remember that a surreptitious book is still a legal publication, most of which were entered into the Stationer's register. ${ }^{96}$

The advantage to such a ruse is that those works published and distributed in England would, or could, mislead the reader into assuming that the pamphlet was an 
illegal import, or that someone else was the author. There was another class of books, published legally in England, commissioned and/or written by crown officers, to be smuggled into Spain for propaganda purposes, becoming thereby the same sort of books the English were trying to stop passing their own borders. William Cecil was active in this area, often in conjunction with John Wolfe. Pamphlets such as The Execution of Justice in England and $A$ Letter to Mendoze, are examples of these sorts of pamphlets--the former translated (from the original English publication) without Cecil's name, or the printer's--appearing in any edition, the latter published for England under the guise of an English Catholic's lamentations over the Armada's defeat. These sorts of works cease with Cecil's death and do not commence again until the reign of James I. ${ }^{97}$

What is most significant about the practice of printing in England, and its regulation under Elizabeth's rule, is the nature of the legally printed pamphlet. The crown's intent in all laws, proclamation, and decrees, was to control the expression of opinion and to confine it within "safe" limits. Publications were loyal and Godly, or they did not become legal publications. Those books which were not written by, or under the auspices of, crown officers, were nonetheless within those allowable limits, and as such reflect the sorts of ideas that the crown was willing to permit-if not promote. I contend, therefore, that any legal pamphlet is at least semi-official in nature--by virtue of its legal status. They are, then, at least reflections of official positions intended for public consumption. It is the nature, and effect, of these opinions which we will examine in the subsequent sections of this study. 
NOTES:

\section{CHAPTER I}

${ }^{1}$ Geoffery Elton, The Tudor Constitution (Cambridge: CUP, 1960), p. 62 elisions, mine. 26 Henry VIII, c 13 (1534):

Be it therefore enacted by the assent and consent of our sovereign Lord the King [with the Lords and Commons] that if any person or persons, ... do maliciously wish, will or desire by words or writing, or by craft imagine, invent, practice or attempt any bodily harm to be done or committed to the King's most royal person . . . being thereof lawfully convict according to the laws and coustoms of this our realm, shall be adjudged traitors. My elisions.

${ }^{2}$ Lacy Baldwin Smith, Treason in Tudor England (Princeton: PUP, 1968), p. 291, n. 48 from Christopher Sutton, Disce Vivere (1604).

${ }^{3}$ Smith, p. 291, n. 48, William Baldwin, Morall Philosophie (1547).

${ }^{4}$ The cosmic dance, with literary accompaniment, may be found in Chapter Eight of E. M. W. Tillyard's, The Elizabethan World Picture (New York: Random House, 1960).

${ }^{5}$ Tillyard, p. 14, quoting Hooker's Laws of Ecclesiastical Polity, elision mine.

${ }^{6}$ Smith, pp. 136-37, gives an account of one such attempt taken from the Cotton Mss. (Titus BII), it is the report of officers attempting to trace the source of a rumor, and runs over five pages.

Sedition, especially seditious speech as a political offence, was a product of the sixteenth century, related to the fifteenth century concept of treasonable words. I have not the space to follow the development of the laws on speech; the reader is directed to Roger B. Manning, "The Origin of the Doctrine of Sedition," in Albion, Vol. 12, No. 2 (Summer 1980), pp. 99-121.

${ }^{7}$ Smith, quoting from Raleigh's Maxims of State. This is precisely what the crown did do, especially in the English seminaries on the Continent.

${ }^{8}$ S. T. Binoff, Tudor England (Harmondsworth: Penguin Books, 1950), p. 220.

9 While the use of the verb "to publish" takes on the meaning of issuing a book as early as 1450 (and is the most common usage today), the broader definition of making public remains the most common in the sixteenth century. See the OED, pp. $1561-2$. 
${ }^{10}$ Katherine F. Pantzer, "Printing the English Statutes, 1484-1640," in Books and Society in History (New York and London: R. R. Bowker Co., 1983), pp. 90-91.

${ }^{11}$ Frederick Seaton Siebert, Freedom of the Press in England (Urbana: U Illinois P, 1952), p. 22.

12 Siebert, pp. 14-15.

1529 papal bull on heretical books

1524 warning to printers (heretical works)

1528 regulation of foreign printers (protectionism)

1529 first English index of prohibited books

1530 first licensing under royal authority 1969), p. 9.

${ }^{13}$ Donald Thomas, $A$ Long Time Burning (London: Routledge \& Kegan Paul,

14 The year 1547 saw three such acts seeking to control rumors: 29 April, 8 July, and 30 October. 1570-71 two acts were published on the importation of bulls (1 July 1570; 1571, 13 Eliz. I, c. 2).

15 Elton, p. 61, 26 Henry VIII, c. 13.

${ }^{16}$ Hughes and Larkin, n. 389, 28 July 1553.

17 Elton, p. 358, 28 Henry VIII, c. 10.

18 Hughes and Larkin, n. 281, 24 May 1547.

19 Hughes and Larkin, n. 390, 18 August 1553, STC 7849.

${ }^{20}$ Hughes and Larkin, n. 389, 28 July 1553.

${ }^{21}$ Hughes and Larkin, n. 699, 1 July 1558.

22 Arber II, p. 807, Star Chamber decree, 3 June 1586.

${ }^{23}$ Arber I, p. 430.

${ }^{24}$ Hughes and Larkin, n. 699.

25 G. W. Prothero, Select Statutes and other Constitutional Documents (Oxford: The Clarendon Press, 1894), p. 165. Quoted from SPD Eliz. 1xxxii, p. 33, the oath as administered to Shrewsbury, 12 December 1570 (n.s.).

26 Colin Clair, A History of Printing in Britain (London: Cassell \& Co., Ltd., 1965), p. 107. P. M. Handover, Printing in London (Cambridge: Harvard UP, 1960), p. 21. W. W. Greg, Some Aspects and Problems of London Publishing (Oxford: The 
Clarendon Press, 1956), p. 1. Clair gives the date as 1403, but Greg (quoting Graham Pollard), agrees with Handover.

${ }^{27}$ E. G. Duff, The Printers, Stationers and Bookbinders of Westminster and London (Oxford: OUP, 1906), p. 41.

${ }^{28}$ Siebert, p. 25. "An Acte Concerning the Taking of Apprentices by Strangers," 14 and 15 Henry VIII, c. 2, prohibited aliens from taking apprentices, and restricted to a minimum of two alien Journeymen printers. Printers were not included in the 1563 Statute of Apprentices.

${ }^{29}$ Clair, p. 107 , the reason for the delay is unclear. Elizabeth confirmed the charter 10 November 1559.

30 Arber I, xxviii-xxxii, 3 and 4 Philip and Mary, part 10, m 46, elision mine. It may be that Mary's final motivation for granting the charter was the flow of Protestant propaganda, rather than protecting the "mistery or art of Stationery."

31 Arber I, p. 92. It is an interesting historiographical note that Arber comments upon the "extremities of misery" from which the nation was saved (such as this act) by Mary's death. The fact that Elizabeth also invoked martial law to stop seditious books (1 July 1588) was apparently not cause for concern; in fact, Arber does not include this act among those quoted.

${ }^{32}$ Handover, p. 26.

33 Graham Pollard, "The English Market for Printed Books," Publishing History, Vol. IV (1978), p. 17. Pollard also notes that between 1562 and 1640, 82 percent of the apprentices came from outside London (p. 16). How much was interest in the trade, how much the pull of the borough?

${ }^{34}$ Clair, p. 108. In some cases they carried this control outside the crown's intent. In 1583, a group of members smashed the press at Cambridge, as the printer was not a stationer. Nicholas Barker, The Oxford University Press (Oxford: The Clarendon Press, 1978), p. 6.

35 Patrick McGrath, Papists and Puritans (London: Blandford Press, 1967), pp. 57, 73, chapter headings.

${ }^{36}$ A. O. Meyer, England and the Catholic Church Under Elizabeth I (London: Routledge and K. Paul, 1967), p. 465. From a letter sent to the Vatican, probably an English Catholic in Rome. Meyer speculates that the date of the letter is late 1559, or early 1560; the source is a manuscript in the Vatican (Arch. Vat., Arm. LXIV, t. 28, fol.s 299, 300). The translation is mine:

Considerato il presente stato del regno d'Inghilterra, il quale novamente é ritornato al scysma et all' heresie [sic] per mera volontà della moderna regenia et contra il sentimento di molti signori principali di quel regno et della maggior parte delli populi, li quali desiderano la religione catholica et l'unione della chiesa. 
Such over-confident estimations of Catholic feeling in England were apparently common among English exiles. The first move to excommunicate Elizabeth came in the early 1560 s--evidently initiated by exile clergy in secret communication with the clerics being held in the Tower. Pius IV (r 1559-65), more interested in England's fate than his predecessor (Paul IV) was enthusiastic and prepared to proceed with the plan until dissuaded by the Holy Roman Emperor, Ferdinand, and King Phillip of Spain, both of whom were unwilling to endanger Hapsburg interests by pushing England toward Valois France. Pius abandoned the idea in 1563. See C. G. Bayne, Anglo-Roman Relations, 1558-1565 (Oxford: The Clarendon Press, 1913), especially Chapter IX, pp. 182-95.

37 Prothero, pp. 23-25, I Elizabeth, c. 5 (1559).

${ }^{38}$ Prothero, p. 228, 19 July 1559; source Patent Rolls, I Elizabeth, part 9.

${ }^{39}$ See Arber I, p. 322, for complete text.

${ }^{40} \mathrm{I}$ have altered $\mathrm{u}, \mathrm{v}$, etc., as stated above.

${ }^{41}$ The charter of the Company had set a fine of 100 s for those who engaged in printing without membership in the guild; half went to the Company, half to the crown. Arber I, p. xxxi.

42 Arber I, p. 430. Arber feels that this was a warning in response to the tensions of the conspiracy brewing in the North. As the act is aimed more toward authors on the Continent, and is similar to previous and subsequent acts, I rather think it is merely coincidental.

${ }^{43}$ See appendix.

${ }^{44}$ H. S. Bennett, English Books and Readers, 1558-1603 (Cambridge: CUP, 1965), p. 3.

45 OED, pp. 554-55.

${ }^{46}$ Of course this remains a problem today, when countries such as the U.S.S.R. and the P.R.C. do not participate in the international agreement.

47 Arber I, p. 111. From a document of about August 1577 listing the copies granted by the crown since Elizabeth's accession (Landsdown Mss. 48).

48 The above mentioned document gives the number of Printers and Stationers in the city as 175 , ten of whom are named as holding rights to print certain categories of books.

49 Plant, pp. 165 and 188.

50 Plant, pp. 186-88. From the earliest printed recipe (Venitian, 1660).

${ }^{51}$ Plant, p. 198. 
52 Plant, p. 203. There were four sheets per quire, and the present standard is $24, \mathrm{OED}, \mathrm{p} .2396$.

53 Plant, p. 203.

54 Plant, p. 176. This later day shortage tended to be in fonts for non-Roman alphabets. These problems meant that at times portions of a text had to be omitted for lack of the proper fonts. The text might be added by hand in the empty spaces, either by the stationer or the patron.

55 Plant, p. 164.

56 Plant, p. 175.

57 Plant, p. 177.

58 Plant, p. 178.

59 Plant, p. 179. It is unclear how this differs from Italic, see above.

60 Arber I, 470.

61 Plant, p. 177. She gives a figure of about four ounces per square inch of type; a quatro page of pica would weigh about 45 pounds (Plant's figure, 180 pounds for four quatro pages, or 90 pounds for a folio (p. 179).

62 Plant, pp. 89-90. John Day averaged seven per year (275 publications, 1546-1584). Queen's printer, Christopher Barker brought out about 120 works (average 4.8 per year) from 1574 to 1599 , but this would have included many broadsides. A report to the Bishop of London in May 1582 listed Day as having four presses, Barker five. Mr. Wolfe, of whom we shall hear more later, had " 3 presses, and 2 more since found in a secret Vaut [sic]." Arber I, p. 248, original uses Roman numerals.

63 Plant, p. 90.

64 Loades, p. 154.

65 Denis B. Woodfield, Surreptitious Printing in England (New York:

Bibliographical Society of America, 1973), p. 6. H. P. Hoppee, "John Wolfe," The Library, 4th Series, Vol. XIV, No. iii (December 1933), pp. 241-289.

66 Handover, p. 38.

67 Woodfield, p. 10.

68 Woodfield, p. 11. He was confirmed 23 July of that year in his new office.

69 Handover, p. 40. 
${ }^{70}$ The first missionaries, Person and Campion, arrived in June 1580.

71 Bennett, p. 75.

${ }^{72}$ McGrath, pp. 120-21. From a letter of Bishop Alymer to Cecil, 30 December 1579.

${ }^{73}$ Bennett, p. 117. Fleetwood was responsible for hunting down recusants, among his other duties, it is in this capacity that he was interested in Carter's work-rather than any concern over the violations of printing regulations.

${ }^{74}$ P. R. Harris, "William Fleetwood ...," Recusant History, Vol. 17, No. 3 (October 1963), p. 114.

75 McGrath, p. 121. Carter was among the 85 English Catholics beatified by John Paul II, 22 November 1987.

${ }^{76}$ For more on Puritan pamphlets, as well as those by the Brownists and the Family of Love, see Milward, Chapter 2 (pp. 25-38). Also Chapter 7 on Puritan v.s. Anglican pamphlets (pp. 154-74). He covers both legal and illegal works.

77 Arber I, p. 144.

${ }^{78}$ Woodfield, p. 8.

${ }^{79}$ Handover, pp. 40-41.

80 Arber II, p. 807. Complete text, pp. 807-812, all quotations from this source.

81 Paragraph 1, p. 808.

82 Paragraph 2, p. 808.

${ }^{83}$ p. 809.

${ }^{84}$ Paragraph 4, pp. 810-11. Paragraph 5 decreed a three month imprisonment for binding illegal works (p. 811). Greg, p. 56, notes that Councilors at times approved their own books, such as Bacon in 1597 and Camden in 1600.
${ }^{85}$ p. 811.
${ }^{86}$ p. 812.
${ }^{87}$ p. 812 .
88
p. 812. 
${ }^{89} \mathrm{Greg}$, p. 52, names in footnotes 2 and 3: Richard Cosin, Thomas Stallard, Richard Wood, Abraham Hartwell, William Gravet, Robert Crowley, William Cotton, William Hutchinson, Richard Judson, Henry Tripp,--Cole, and George Dickens. The only surviving record of this provision is in a 3 June 1588 entry contained in CourtBook "B." Records of approvals were to be entered into the Hall Book.

90 Conyers Read, "William Cecil and Elizabethan Public Relations," in Elizabethan Government and Society (London: The Athlone Press, 1961), pp. 30-31.

${ }^{91}$ Read, p. 22. The last example, for which there are three drafts, was published in April 1591.

92 Read, p. 25. It was released for publication in 1561; Jewel's Latin edition and Ann Bacon's English translation were published the next year.

${ }^{93}$ Read, p. 26. Although written in 1570 , it was not published until 1582.

${ }^{94}$ Circulation of works in manuscript continued quite late in England, which is why scriveners lasted longer there. Gentlemen did not publish in print--although a friend might do so without permission, or at least claim that such was the case. Plant, p. 23.

95 Woodfield, p. vii. Books published in Catholic countries were required by the Council of Trent to carry an imprint (p. 2). Some Catholic books printed secretly in England carried Continental imprints as well.

${ }^{96}$ Woodfield, p. vii, emphasis mine. An example of the last case is the use of "Ricardo del Campo," by Richard Field. There are no fictitious imprints between 1550 and 1580 (p. 1).

97 Woodfield, p. 41, no known works of this type 1598-1612.

A very different, but nonetheless significant, class of pamphlets published with government aid were the writings of the Appellants. The interment of Catholic priest at Wisbeach Castle (Oxfordshire), meant that the various sorts of men were thrown together, eventually including Jesuits as well as secular priests. What had begun as an apparent personality conflict between the secular and the Jesuits developed into a full blown battle and resulted in a split among the priests. Two appeals (hence the name) were made by the seculars to Rome requesting the Jesuits leave England; the second was financed by the crown. Both groups carried on the war in print, but Appellant pamphlets were printed in England on legal presses at the government's connivance, under false imprints. They were ordered suppressed by the Holy See. Although they fall outside the scope of this paper, they are as vicious as any Puritan in their attack on the Jesuits, who seemed to them the cause of Catholic troubles in England. 


\section{CHAPTER II}

\section{THE SCOPE OF THEIR LABORS}

[T] he whole scope of their labors is manifestly proved to be secretly to win all people with whom they dare deal so to allow of the Pope's said bulls and of his authority without exceptions as, in obeying thereof, they take themselves fully discharged of their allegiance and obedience to their lawful prince and country ... and to be ready to secretly join with any foreign force that can be procured to invade the realm ... the effect of the labors is to bring the realm not strangers, . . but into a war domestical and civil. ${ }^{1}$

The shifting fortunes of sixteenth century England, both religious and political, were taking their toll by the reign of Elizabeth. Uncertainties over the Tudor dynasty's continued existence, coupled with the rapid shifts between Catholicism and Protestantism, under Henry VIII's children, did little to assure Englishmen that the order of the cosmos would remain unshaken.

If the Elizabethans believed in an ideal order animating earthly order, they were terrified lest it should be upset, and appalled by the visible tokens of disorder that suggested its upsetting. They were obsessed by the fear of chaos and the fact of mutability; and the obsession was powerful in proportion as their faith in the cosmic order was strong. ${ }^{2}$

The ideal of an ordered, unified, world in which everyone and everything had its place and purpose was increasingly challenged by evidences of defiance and disunity of all that had seemed to compose the world. The links of the Great Chain were straining, and the disaster of a break appeared to be an increasing possibility.

Elizabeth Tudor's accession, while it assured the official return of Protestantism, could neither blow away the smoke of Smithfield, nor calm the fears for 
the future of the realm. Would she send a representative to Trent? Would the radical Protestants be allowed to revive all of the Edwardian changes? The first decade of her reign slowly revealed a more Henrician solution for the question of a state religion, shifting rather than solving the problems, satisfying the center and thus making the extremes appear more threatening to the stability of the crown.

The more order is seen to be menaced, the more tightly people cling to it, or its illusion. As the real and ephemeral threats swirled about them, Queen Elizabeth's Englishmen reached out in desperation hoping to find the cause of their troubles, and somehow put a stop to it. Somewhere there was a source, if it could be found perhaps the world in which they lived could be saved from its annihilation.

1570 was a watershed year for English opinion. Smoldering fears of the previous years, which had been fanned into flames by the Northern Rebellion, now exploded with the promulgation of the bull of excommunication, Regnans in Excelsis. Tensions, fears, and distrust, waxed with the new problems implied by the excommunication of the monarch.

Carol Wiener has used the word "anxiety" to describe this tension. ${ }^{3}$ William Bouwsma examined the use of this term, and its applications to societies as early as the Hellenistic world. He does point out that the Medieval anxietas, with its vague notions of "weariness or distress of the heart," had broadened by the sixteenth century, and in addition, notes that the words "anxiety," and "anxious" entered the English language in the sixteenth and seventeenth centuries. ${ }^{4}$ He defines the term more closely:

Fear is distinguishable from anxiety by the specificity of its object; . . . [y]et the relationship between anxiety and fear remains close, for behind the fear of a particular danger always lurks, again uncertainty about its eventual outcome. 5 
It is that need for an object of focus which is so palpable, and which makes English anti-Catholic ideology so potent a force. Yet as we shall see, that sword had two edges: that which united the Protestant Englishmen against a perceived foe, and the other, which cut away at their feelings of security and created "unnecessary anxieties, misconceptions, and mistakes."6

The vehemence with which anti-Catholic pamphleteers seized upon this newmade solution, and the tenacity with which they clung to it is hardly unique to sixteenth century England, Richard Hofstadter had labeled it the "paranoid style."7 While paranoia is an anachronistic term (not used in English until 1857), ${ }^{8}$ Hofstadter does not refer to clinical paranoia as suffered by an individual, but to a broader, nonclinical use, "Much as the historian of art might speak of the baroque or mannerist style. ${ }^{\text {"9 }}$ More specifically:

[T]he spokesman of the paranoid style finds it directed against a nation, a culture, a way of life whose fate affects not himself alone but millions of others. [. . .] Style had to do with the way in which ideas are believed and advocated rather than the truth or falsity of their content. ${ }^{10}$

He then identifies the seven basic elements of the style:

1. There is the image of a large, evil conspiracy which is "the motive force in historical events."

2. "The apocalypticism [sic] of the paranoid style runs dangerously near to hopeless pessimism, but usually stops short of it."

3. Even when there are successes the feeling of the powerlessness of the nation remains, and re-enforces the realization of the enemy's power.

4. There is the belief that somehow the opponent is not subject to the fortunes of the world as "we" are, but is instead controlling and directing actions and opinions, i.e. through elements such as brainwashing--or the confessional.

5. Works in this style use the testimonial "evidence" of renegades, or re-converts to "our" side. 
6. There is an "elaborate concern with demonstration."

7. Arguments begin with "defensible assumption ... [and] careful accumulation of facts." These elements are the "careful preparation for the big leap from the undeniable to the unbelievable. ${ }^{\text {III }}$

All seven criteria not only exist, but abound in the anti-Catholic literature we will examine.

If there is an element which is not present in the paranoid style, Hofstadter informs us, it is "sensible judgement about what can cause a revolution. ${ }^{n / 2}$ Wiener emphasizes the over-estimation of the power of the pope as shown in the body of antiCatholic works, especially in the influences over the Spanish throne. ${ }^{13}$ This element of paranoid style is, I believe, a direct result of the model of order which the writer holds. It is hardly surprising that a society which had so robust a concept of the nature and structure of the cosmos could see this element of dissent only as a strong and unified attack on all that God had ordained, hence the "apocalyptic" nature with which that dissent was endowed.

For the English Catholics themselves, the excommunication was hardly a victory. Their belief in unity, too, had been dealt a heavy blow--in many ways a more devastating one than the Protestants had sustained. If God was not yet an Englishman, he was certainly a Protestant, at least by statute. ${ }^{14}$ His worship was only properly observed in the established church, headed by the crown. To be a loyal Englishman, one must be a Protestant; to go to heaven one must be Catholic. To be an observant Catholic of unquestioned loyalty was impossible. ${ }^{15}$

This did not stop the Catholics, Jesuits as well as Appellant writers, from issuing protests of loyalty which must reflect the sentiments held since the seventies: 
And can any imagine us to be so simple, that we cannot see hoe impossible it is for Catholikes to do the king [of Spain] any good, though they were as much bent that way as their accusers would have thought: doe we not see that they are scattered one among thousandes. ... [I]t can neyther benefit us, nor avail them [the Spanish]: but rather draw upon us both a manifest subversion. ${ }^{16}$

And why should wee the Catholikes of England sute our fidelities and love (I say not our religion) to our Protestant-Princesse, as well as the Protestants of Fraunce doe theirs to their Catholike king . . . ? ${ }^{17}$

If the Catholics held out any hope for accommodation, or at least toleration (and the Appellants clung to that hope longer than most), it was a delusion. Not only the Act of Uniformity, but the fundamental concept stood in their way. As early as 1563 , the Queen had stated the unwavering position of the realm:

[T]o found churches expressly for diverse rites, besides being openly repugnant to the enactments of our supreme Parliament would be but to graft religion upon religion, to the distraction of good men's minds and fostering of the zeal of the factious, the sorry blending of functions of church and state, and the utter confounding of all things human and divine in this our now peaceful state ... [it is] neither advantageous nor indeed without peril. ${ }^{18}$

While the queen's concern over the mixing of church and state is rather disingenuous, the worry over "faction" is not.

That Regnans marked a departure was clear from the beginning, as was the triumph of fervor over fact. It followed so closely on the heels of the Northern Rebellion (November 1569), that their linking was a simple task, although there was a three month gap between the rising and the excommunication. Most Catholics were likely unaware of the bull's existence "until 1571 or even, perhaps, until the arrival of the missionaries." Fact, however, soon gave way to fiction. As early as that year (1570), a pamphlet was published claiming that the rebels had the bull at the time of the rising. Thomas Norton, a Puritan and Member of Parliament, originated this 
fiction, or at least was the first to put it into print. ${ }^{19} \mathrm{He}$ not only asserted that the bull's promulgation had preceded the rebellion, ${ }^{20}$ but in an additional pamphlet, he admitted that he had confused two different bulls, then repeats the charge. ${ }^{21} \mathrm{~A}$ broadside ballad of the same period which rails against Catholic disloyalty, and popish evil, does not mention the bull. ${ }^{22}$ There is no evidence, of which I am aware, to point to a deliberate lie on Norton's part; there are no doubts, however, over his violent anti-Catholicism. His willingness to examine Catholics under torture (often at the hands of the notorious Topcliffe) earned him the title of Rackmaster General among Catholics. $^{23}$ It does seem strange than an M.P. who was made Remembrancer to the City of London the following February should be so unaware of the sequence of events.

There does seem to be, however, at least one possible source for the confusion. Thomas Markenfield, one of the rebels, may have set the rumors in motion when, in answer to objections and doubts about the legitimate nature of their rebellion without a bull, he justified the action "by maintaining that 'the Queen was excommunicated when she refused to suffer the Pope to send his ambassador to her presence. $^{\text {m24 }}$ It is likely the question may never be settled.

Whatever the impetus, the link between the events became an established "fact" repeated in other writer's pamphlets, e.g., Anthony Munday (1582), William Cecil (1584), and Thomas Bell (1603). ${ }^{25}$ Bell claimed that the pope "joined with" Northumberland and Westmoreland by excommunicating the queen, and sending two priests to England with the bull. ${ }^{26}$

The involvement of the See of Rome, in the person of Pius V, or the lack of the same, becomes a moot point. However the political historian may sort out the 
events and intentions surrounding the Rebellion and the bull, it is not the actions themselves, but it is the myths which become "facts" that are the most dynamic. Events are moved by what people believe, or wish to believe. The assumed involvement of the pope was the driving force behind all anti-Catholic action because it fit their notions of Rome, whatever the real situation might be. ${ }^{27}$

Having cast their fate to the Protestant wind, the English embraced their new Truth. What manifested itself as a "paranoid style" in writing was a siege mentality in politics and daily life. It was clear to them that the pope (whoever the individual on the throne of Peter might be), was the hand guiding those "motive forces" of their history. The pope was the dread general of the horrible army set to destroy them. It did not matter, in the end, who was filling the Fisherman's shoes; there was but one goal--England's utter destruction. The terms "Pope" and "Anti-Christ" became cliches in the genre because they function so effectively as a shorthand reminder of the significance of the battle. The enemy has but one goal; it does not matter which individual commands the troops, the orders remain the same.

John Baxter, in his 1600 work, does discuss actions of particular men (as well as pope Joan), but quickly returns to the safe ground of The Pope and his actions. ${ }^{28}$ Marten does not even bother with the possibility of multiple popes, but displays a sort of Ur-Pope for all to see:

It was that man of sinne which caused the commotion of the North against King Henry the eight. It was he that raised up divers Rebellion against that vertous young prince king Edward the sixt, and also against her Majestie. ${ }^{29}$

If the pope was leading the forces against England, then surely English Catholics must be a part of that army. Their assertions of loyalty were mere cover for their heinous 
designs: "[T]he Pope licenseth the papists to dissemble their obedience until publick execution of the Bull may bee had: that is to be privy traytours, till with hope of success, they may bee open rebelles." ${ }^{30}$

Written in 1602, Josias Nichols's pamphlet illustrates that the year 1570 had already been transformed into the dividing line of loyalty. Since that time the papists were "never beeing without one cruell treason or another; sometime by desperate bluddie murders: sometime by open rebellion, [or] forraine invasion." ${ }^{31}$

If the tide of anti-Catholic propaganda had turned in 1570 , it did not reach full flood until the 1580s. Although missionaries from the Continental seminaries had been arriving since the mid-seventies, the Jesuits did not join them until the next decade. $^{32}$ The reputation of the Society for missionary fervor had already been well established. Campion's and Persons's arrival in England coincided with the ill fated trip of Saunders to Ireland--and event of which the Jesuits were unaware, but which reinforced the perceptions of a threat. ${ }^{33}$ The Jesuit presence in England intensified the concern of the Protestant majority to the point of virtual panic; distrust became an art.

Lacy Baldwin Smith's examination of the period shows a general distrust, evidenced, among other things, by the innumerable warnings by fathers to sons to take care of whom they put their faith in. ${ }^{34}$ Seeming was not being; deception was everywhere, if one but looked:

Why then your co[n]science doth declare

A guilty mind that shuns the light, A spotless conscience need not feare, The tongues of men, nor yet the sight, Your secret slides doe pass my skill, And plainely show your workes are will. ${ }^{35}$ 
Such suspicion is echoed in John Fielde's 1581 work, but not directed at the dissembling "Catholiques": "Beware of flatteryes of these double tongs [sic], their mouths are full of guile, the poison of Aspes is under their lips. As low they croatch, fast as they weep, ... what Crocadiles they are." ${ }^{136}$ The "dynamic union" and the possibility of imminent revolt, and the identification of THE ENEMY is evidenced here. The source of the ills of England having been clearly identified as the papists, one can no longer trust any of their actions, or protestations of innocence. Every waking moment of their lives was surely spent in devising new ways to destroy the very existence of the realm; likely their dreams were also so directed.

Fielde points to the "seditious and traiterous" books meant to stir up rebellions. ${ }^{37}$ Every action of the English papists point to but one conclusion:

What other thing can it argue, but that you are such dangerous enemies, as they have good cause under her majestie, chiefly to watch against, to have a diligent eye to the maintenance of the gospell, and to the preservation of her majesties royal person the defender of the same, to whom (as faire shewes as you make) $a$ [sic] you wish no good. ${ }^{38}$

Former seminarian John Nichols, after his recantation in the Tower, promised that now he was suitably Protestant: "I shal become of a Rebell a true subject, of an enemie of the trueth, an embracer thereof." ${ }^{39}$ If one could put trust in anything, it was the fact that deception and betrayal lurked everywhere, and was but waiting for the best chance to triumph.

The casting of anti-Catholic action in terms of treason, rather than religious belief, became the pivot point of official and unofficial writings. With visions of Smithfield dancing in their heads, the Protestant government was handed, in effect, a golden opportunity to re-cast the problem in secular terms. If the Catholics of England had been released from their bounden obedience to the throne, then any 
action taken against them was to forestall treason, or combat it. In the wake of Regnans, Catholics dying at Smithfield were punished for treason, not their religion. Elizabeth Tudor would never stoop to religious persecution; there could be no Catholic Foxe. The effort was effective enough to permanently cast the situation in crown terms, that is to assert: "[a]fter the excommunication, propaganda against the Roman Catholics was directed not against their theology but against their politics. ${ }^{40}$ We shall see that this confident assertion does not acknowledge the realities of the situation.

Since, now, Catholicism meant treason, then the mere presence of Catholics in England was a source of real and constant danger which could not be allowed without peril:

Nothing in the world grieveth me more than to see her Majesty believes that this increase of Papists in her realm can be no danger to her. . . If she suffers this increase but one year more, as she hath done these two or three past, it will be too late to give or take council to help it. ${ }^{4 I}$

But the officers of the crown were not sleeping. They knew the actions of the papist horde waited only for the right moment, and they knew how the thing was to be accomplished:

[I] was devised to errect certain schools which they called seminaries, to nourish and bring up persons disposed naturally to sedition, to continue their race and trade and to become seedmen in their tillage of sedition. ${ }^{42}$

These priests had no care for the souls of good Christians, but were eager to pull down the edifice that centuries of English striving had achieved. Should the queen stand by and allow such depravity to continue:

shall she forbear or fear to withstand and make frustrate [the pope's] unlawfull atempts, wither by her sword or by her laws, or to put his soldiers, invaders of her realm, to the sword martially, or to execute her laws upon her own rebellious subjects civilly, that are proved to be his chief instruments for rebellion and for his open war? ${ }^{43}$ 
The crown and its loyal subjects certainly would not allow this, nor would the "seditious trumpeters of imfamies and lies" ${ }^{14}$ be permitted to sound their charges of religious persecution unanswered: "[f]or I boldly affirm that they cannot prove that any one received the Romish religion, except treason were there unto also annexed." ${ }^{45}$

"Wherefore I conclude upon these reasons, that a proffesed and absolute papist, priest, Jesuite, pope catholike, lay, regular, or secular, can be no good subject, though he may be no traytour. ${ }^{466}$ It was, then, a settled thing.

Anti-Catholic pamphlets were not only good politics, they could be lucrative as well. Wiener has identified the government's hand in 15 of the 116 pamphlets she studied $;{ }^{47}$ and counted 74 different men as publishers. ${ }^{48}$ If we are to find any measure of "popular opinion" (or at least popular taste among readers), this may be an indication. Anthony Munday was living with his publisher while writing his brief Answer, and might have had financial assistance from the same source on his trip to Rome, which produced the "profitable expose" The English Romayne Life. ${ }^{49}$

A study of the groups involved in producing the pamphlets indicates that they were in fact, responding to popular demand ... [and] would seem to indicate that anti-Catholic books were not the work of a few cooperating stationers, they were published for the same reasons that they produced any other books. . . A Anti-Catholicism was good business. ${ }^{50}$

That authors, and especially stationers, were willing to venture into the financial risks of publishing these pamphlets is at least one indication that a market existed for antiCatholic literature; a market which was strong enough to be self-sustaining even after direct government efforts at spreading anti-papist opinion in print had ceased.

Not only publishers, but authors as well, saw the anti-Catholic pamphlet as a prospective way to fame and fortune. George Whetstone, a native of London, probably published his 1587 pamphlet on the Babington Plot in hopes of attracting at 
least some money, and perhaps fame. He claimed to be a relation of the City Recorder, Fleetwood, and was related to a wealthy Lincolnshire family. He apparently spent his patrimony on riotous living as a youth, then turned to denouncing the wild life of London, and attempting to get his money back in the courts of law. He served with distinction in the Lowlands as a soldier, but returned to a financial situation little improved. He addressed "poetic panegyrics" to men and women at court in a vain attempt to gain patronage. Read styles him as "a literary adventurer of some experience"; the DNB, however, disparages his talent. His pamphlet The Censure of a louyall Subject, was published just before the execution of Mary, Queen of Scots, and reissued just after, apparently too late for George, who seems to have died shortly after the reissue. ${ }^{51}$

While, as Read asserts, "it is difficult to distinguish between official and unofficial pamphlets, government issues from publishers' ventures, ${ }^{, 52}$ both the nature of legal restrictions on printing, and the evidence of commercial demand, would suggest that such distinctions are at a basic level unimportant. If a printer was willing to risk the financial outlay for a pamphlet, some market must have existed. One can only speculate upon the reasons for such a demand. Certainly there would be a hunger for news of the situation both in the country and abroad. Pamphlets reported on the goings on of the government in London, as well as actions taken by foreign princes, and the state of affairs of Protestants doomed to live in Catholic lands. Some described the fitting end of the Catholic clergy who dared to disturb the peace of the realm; others detailed the stratagems by which the Romans would come and take the nation; still another group followed Foxe by describing in lurid detail the ways in which Protestants were tortured and killed while clinging to the true faith. Most pamphlets 
were combinations. Hofstadter calls anti-Catholicism "the pornography of the Puritan, ${ }^{53}$ but I think a better comparison might be with horror films and literature. Even now the reader may catch the hint of that thrill of fear and dismay that must have seized the Elizabethan reader. Would the Catholic vampire sink its teeth into the vulnerable neck of the Protestant maiden--or would the hero appear at the last moment to save her--and who would the hero be?

Yet will not these examples good Once stay these traitors madding mood But still they seeke to suck the blood, of our gratious Queen of England. ${ }^{54}$

There is, after all, a certain titillation in dancing on the edge of disaster.

Both official and unofficial voices are characterized by an overwhelming sense of exasperation with the blind bull-headedness of the papists. The truth of the situation is so clear, and their error so obvious, yet they will not admit that they are wrong. Ministers preach the truth, the crown legislates the truth, yet the papists ignore it. Therefore, of course, any catastrophe which befalls them is their own fault: "[see] the wrong way you walk in, how you wishe your own woe, seeke your owne sorrowe, and desire your destruction. ${ }^{n 5}$ If the papists are in danger, it is because they wish to be. If the tales of their doings offended the reader, it was not the author's fault: "blame not me gentle Reader but ye importunitye of ye Papistes, who hath forced me thus to display their treachery. ${ }^{56}$ There are no victims, only blame.

Everyone that sayeth otherwise then is set furth, althoughe he seme to bee worthye of credite, althoughe he fast, althoughe he worke wonders, althoughe he Prophesie, yet take him to bee a Wolfe amonge the floake of shiepe, seking to destroye them. ${ }^{57}$

Another source of concern was the effect of the actions and writings of the Catholics upon the common folk. Some writers hoped that sage words might divert the 
simple from the siren songs of Rome. Lupton informed his dedicatee, the queen, that while the worst papists might not be turned from their intended ends, the lesser sort of men might be.

And though it procure not the obstinate and determined Papistes, from being Englishe Enimies: yet it will enforce thousands (I hope) of the simple suduced sorte, to become English friendes (or rather friendes to England). ${ }^{58}$

The base sort of person is easily swayed. While these are not the principle men, who are actually running the nation, like dominoes their fall could bode the end: "for such little sparks may serve the Popes turne, by being kindled into a flame, and that his wilines is a ware of. ${ }^{\text {.59 }}$

Most of the pamphlets of the period have the feel of generic literature, in that they are virtually interchangeable. All praise, all condemnation, all adjectives, and many turns of phrase are used so often that they nearly cease to have meaning as the authors "stuffe their bookes full with cursing and rayling." ${ }^{60}$ John Baxter has no entry in the DNB, but his book, $A$ Toile for Two-legged Foxes, is so clever and well written that one can be swept away by its style, and forget the nature of its anti-Catholic the contents. Baxter informs the reader that there are two sorts of enemies of the true church, those from without are wolves, from within are foxes. Old Reynard, the pope, and his Jesuitical fox cubs are determined to destroy religion and the nation. The metaphor is carried throughout the book, and its primary thrust is to point out the dangers presented by the Catholic presence in the country. The same themes reappear: absolute distrust of Catholic actions and motives. His "contrimen dengerous" trust Spain against all reason--"if not so farre alienated from loyaltie, you art unworthy of the name countrimen." ${ }^{\text {} 61}$ They are intent upon persuading others "first against 
religion [and] secondly against loialty. ${ }^{62}$ Successive chapters rehearse the reasons which impel, indeed require, the nation to take action.

Chapter Nine of $A$ Toile gives eight reasons "proving all perfect papists rottenhearted subjects to all true christian princes." ${ }^{63}$ The list warns that the Catholics cannot be trusted because:

1. They do not attend Anglican services "which would direct their consciences both in duty towards God, and loyaltie towards their prince."

2. They maintain the pope's right to excommunicate the queen.

3. They will obey civil law only as long as the pope allows.

4. They read the Catholic pamphlets against the queen.

5. They receive absolution from the Roman church to be free of the requirements of civil obedience.

6. The papists harbor Jesuits and seminary priests (a danger to the realm).

7. They are looking toward the queen's death for the establishment of a new order.

8. They will let nothing stand in the way of a worldwide Catholic triumph. ${ }^{64}$ The next chapter gives "Twelve reasons proving by divinity and true Christian pollcie, that Foxes must be taken." Among these he repeats the problems of the threat to civil order, that the Catholic are traitors to Christ, that it is a sin to acquire the guilty, and by ignoring the situation the nation is nurturing a serpent in its bosom. ${ }^{65}$ The remedy to all these ills is outlined in the introduction to Chapter Thirteen: that is if the Word is truly preached, and good laws duly executed, the land may achieve "the miserable end of traitours. ${ }^{\text {66 }}$ 
The Catholics were not the only perceived threat to the cosmic order; the radical Protestants for whom the settlement of the religious question had not gone far enough, were also a danger in the eyes of many. Sandys affirmed "Let conformity and unity in religion be provided for and it shall be as a wall of defense unto this realm. ${ }^{67}$ Parker was more to the point: "Papists and precisians have but one mark to shoot at plain disobedience." ${ }^{\prime 68}$ Willet, in comparing the Jesuits to the Puritans, found the former "not so absurd in doctrine, nor yet so malitious against the commonwealth," in addition the Jesuits were "much finer witts then [sic] the puritans." ${ }^{69}$ This did not mean, of course, that the Jesuits could be trusted.

For all their trouble making, the Puritans could also be useful weapons against the papists. Just as the splits among the Catholics were exploited to put more weapons against Rome into print, so the Puritans could be turned against the common enemy of all Protestants. Wiener has identified only 16 of her 116 work sample of surviving pamphlets as specifically "Puritan or otherwise." ${ }^{\text {"7o }}$ There are Puritan voices to be found, whether making a general condemnation of the dangers of papistry, or, like Josias Nichols protesting virtue in comparison to the vices of the Romish crowd.

Puritans, we are assured, are loyal:

But all Papists, if they be true catholikes (as they terme themselves) and namelie all Priests, Secular, Seminarie and Jesuit, doe hold cleane contradictorie, even manifest treason and rebellion against the civil power ordained of God. ${ }^{71}$

There is also the sort of vicious glee evidenced by men like Norton looking to get even with the murderers of Smithfield.

The men who now came swarming back from exile or out of hiding would have been something less or more than human if none of them had any notion of paying back their late oppressors on their own coin, persecution 
for persecution, always, of course, from the highest motives and in the name of religious unity. ${ }^{2}$

Their sons were no less eager to join the fray. Willet, for all of his dislike of the radicals, voiced what must have been the crown's feeling as well, when in his sneer at "Martin Marprelate" he admitted "such a puritan may prove a good stoke to graffe a papist in. ${ }^{173}$

Whatever the writer's personal affiliation, there was little variation in the thrust and scope of their attacks, which might be summed up by quoting the title page of William Lightfoot's 1587 work:

\section{The Complaint of England}

Wherein it is clearely prooved that the practices of Traitrous Papists against the state of this Realme, and the person of her Majestie, are in Divinitie unlawfull, odious in Nature, and ridiculous in pollicie.

In the which they are reprooved of wilfull blindnes, in that they see not the filthines of the Romish government: and convinced of desperate madness, in that they feare not the mischiefe of Spanish invasion: The former whereof is exemplified by the Popes practices both here in England, and abroad in other countries: the later by Spaniards outrages, in his exactions raised upon Naples, and his tyrannies executed in the Indies.

Lastly the necessitie, and the benefits of the late proceeding in justice are set downe; with a friendly, warning to seditious Papists for their amendment; and an effectuall consolation to faithfull subjectes for their incouragement. $^{74}$

It would seem that one need hardly read the book: yet this is not mere Elizabethan wordiness; printers advertised their wares by posting the title pages of new pamphlets in various places about the city. In effect then, these became broadsides, and were accessible, along with their message, to any who could read, or be read to. ${ }^{75}$

There is, then, a double message to be found in the pamphlets which eddied about the streets. There is the vigilance with the officers of the crown watched for 
signs of disobedience and moved to stop it and the clear hand of God in the successes the nation enjoyed: "And here with I am astonished what I may best thinke of such a worke so long in framing, to be so suddenly overthrown, as by no reason could proceede of man, or of any earthly power, but onely of God." ${ }^{76}$ Victory, one is assured, if not in grasp, is at least in view.

Yet there is also the constant tension inherent in the possibility that the enemy might snatch victory from the hands of the just. The emphasis in paranoid literature, after all, is not how well the side of virtue is succeeding, but the strength and cleverness of the powers of darkness. Priests lurk everywhere, the reader is warned, and floods of them hit the shores of England daily. They are hidden in every part of the realm by papists who wish nothing so much as the overthrow of the governing powers, the torture and murder of innocent Protestants, and the surrender of the realm to the hegemony of the anti-Christ.

[T] he real mystery for one who reads the primary works of paranoid scholarship, it is not how the [nation] had been brought to its present dangerous position, but how it had managed to survive at all. ${ }^{77}$

[D]espite the official optimism of Protestantism in general and of the Book of Martyrs in particular, many subjects of Elizabeth and James remained extremely pessimistic about the future, more impressed with the apocalyptic proportions of the enemy that their own capacity to subdue him. ${ }^{78}$

This is to be expected when one's image of the opposition is an immortal, The Pope, who leads a solid block of maniacal followers covering the known world, and sending troops to the newest found portions of the globe. Despite the testimony of apostate papists, despite the obvious splits in opinion over political action of the Holy See, despite the willingness of crown officers with papist leanings to prosecute the Catholics guilty of treasonable offenses, despite every evidence of Catholic fragmentation, all that 
would be acknowledged was the monolithic threat that Rome presented. Leicester's letter to Walshingham laments that the queen allows the number of Catholics to grow, not seeing there is danger, one more year is all that is needed--then it will be too late to act. Action could save the nation, but the proper authorities, indeed the monarch, are letting the last chance slip away. Perhaps the protests of leniency are true, too true, perhaps the lack of vigor in attacking this papist danger will bring the downfall of all good men:

[The government's] trespass in deede is onely herein, that they [the Catholics] are dealte with but to gently, considering their continuall attempts against her highness estate, croune, and dignity. ${ }^{79}$

Puritan writers protested that their loyalty was sure, despite their reservations over Anglican services, after all they were at least Protestants. The Appellant writers protested that they, too, were loyal; despite their Catholicism, after all, they were not Jesuits. They went so far as to propose a loyalty oath they were willing to take to assure their obedience:

I do unfeignedly profess and affirm that I will ever by ready with my body and goods to withstand to mine uttermost power and ability any such forcible and violent attempts with the like faith and true allegiance that becometh all dutiful subjects of any other Christian prince to with stand any enemy that shall seek by force of arms, of malice, and without just cause, to invade, or assault any of their possessions, dominions or countries. $^{80}$

Such equivocal nonsense was dismissed out of hand by the queen.

Identifying the danger which confronts one is a relief, but not a total one. Having put the Catholics firmly in the spotlight only heightened the sense of danger. Here was a foe which threatened not only from across the Continent, but across the lane as well. That actual attempts at revolt that occurred added to the fears, and obscured the fact that they were small, unorganized and tended to collapse under their 
own weight. Even the larger foreign threat of the Armada, loomed out of the proportion to its likely success. Fear fed upon itself. When no real threat existed, one must be manufactured. Willet's assertion that a Catholic "can be no good subject, though he be no traytour," is not just the convoluted thinking of one pamphleteer, but the first maxim of the true Englishman. Whatever the papists did was to harm the realm, if they did nothing it was merely a blind for the fact that they were either planning action, or waiting for past efforts to bear fruit. ${ }^{81}$ "Papistes flie not, stirre not, brag not, nor so anything, nor leave anything done without hope."82 "[E]ven though we should have no word or deed to charge against you, yet we have your silence, and that is a sign of your evil intention and a sure proof of malice. ${ }^{83}$

Distrust poisoned everything, and having been given a target at which to aim, the English clung to their new found answers in the face of all contrary evidence. God was on the side of the Protestant English--but what would happen if He removed His hand? 
NOTES:

CHAPTER II

1 William Cecil, The Execution of Justice in England (Ithica: Cornell UP, 1965), 1584 edition; pp. 8-9, hereafter cited as Ex., elisions mine.

2 Tillyard, p. 16.

${ }^{3}$ Wiener, p. 29, where she describes it as "insuperable anxiety."

${ }^{4}$ William Bouwsma, "Anxiety and the Formation of Early Modern Culture," in After the Reformation (n.c.: University of Pennsylvania Press, 1980), p. 217.

The OED gives the first usage of anxiety as 1525 , by Thomas More, the next by Donne in 1631. The earliest use of anxious is by Cockeram in 1623 (p. 378)

5 Bouwsma, p. 222.

${ }^{6}$ Wiener, p. 60. She feels that both Haller and William Lamont (in Godly Rule, London, 1969) ignore "the former implicitly, the latter quite explicitly," the failure of Foxe's work (and I would argue all anti-Catholic literature), to give the English certainty about the future victory over their enemies (p. 28). Peter Lake agrees, but feels that Wiener may have "failed to realize" both this anxiety and the proclaimed confidence in the eventual Protestant victory became a "dynamic union," each element feeding off the other. See his article "The Significance of the Elizabethan Identification of the Pope as Antichrist," Journal of Ecclesiastical History, Vol. 31, No. 2 (April 1980), p. 168.

${ }^{7}$ Richard Hofstadter, The Paranoid Style in American Politics (New York: Alfred A. Knopf, 1965). He allows for a broader application of the term, asserting that paranoid style "is no more limited to American experience than it is to our contemporaries" (p. 6). L. S. Smith subtitles his book, Treason, "Politics and Paranoia."

8 OED, p. 2074.

${ }^{9}$ Hofstadter, p. 4.

${ }^{10}$ Hofstadter, pp. 4-5.

${ }^{11}$ Hofstadter, pp. 29-38, passim, emphasis his.

12 Hofstadter, p. 37.

13 Wiener, p. 35. 
${ }^{14}$ As early as 1587 , due to the queen's and the nation's continued survival, Job Throckmorton, an M.P., declared "indeed the Lord hath vowed himself to be English." After Armada the feeling was even stronger--if tempered by the fear of future Spanish actions. Conrad Russell, The Crisis of Parliaments (London: OUP, 1971), p. 281.

15 The fact that the bull was made non-binding on the faithful, for the moment, in consideration of the realities of the situation for Catholics, did not impress the crown. While Edward Somerset, Fourth Earl Worcester, might be considered loyal while being a "stiff papist," the question of choosing between recusancy and church papism was for many Catholics the other divide of loyalty, especially with the arrival of the Jesuits, and their clear opinion on the subject. It was to be yet another element adding to the tensions within the English Catholic community.

${ }^{16}$ Robert Southwell, An humble Supplication to her majestie (1600, bears false date of 1599), pp. 26-27. He was a Jesuit.

Subversion is used here in the sense of destruction or overthrow of plans, see OED, p. 3133.

17 Anthony Copely, Answere to a Letter (London: n. print., 1601) p. 71 . He mentions less loyal types, such as Munzer, who had taken up the sword for Protestantism (p. 66). Copley's pamphlet was an Appellant attack on the Jesuits as noted above it was printed with crown aid on a legal press.

For a complete review of the discussions before the decision to send the mission and the terms placed on the men, see E. E. Reynolds, Colmpion and Parsons (London: Sheed and Ward, 1980), pp. 30-35; 61-67.

18 William P. Haugaard, Elizabeth and the English Reformation (Cambridge: CUP, 1968), p. 324, elision mine. Letter to HRE Ferdinand, 24 September, he had suggested some Catholic churches might be allowed in England.

19 Wiener, p. 31.

${ }^{20}$ Thomas North, A Bull granted by the Pope to Doctor Harding (London: John Day [1570]), fol. Bii, r., hereafter cited as Bull.

${ }^{21}$ Thomas Norton, An addition declaritorie ([London: John Day, 1570]), fol. Aiii, r., hereafter cited as $A d d$. He feared being another Cassandra.

${ }^{22}$ W[illiam] E[Iderton], "A ballat intitled Northomberland Newes" broadside (London: Thomas Purfoote, 1569/70). Date of entry is unclear in the STC; Arber gives no entries before 1576. Stanza 13 mentions "The Westmerland Bull," but it is a heraldic reference.

${ }^{23}$ See DNB, Vol. XIV, pp. 666-670. Norton had served Edward Seymour Duke of Somerset, andwas sent to meet with Calvin in 1552; he was the first to 
translate Calvin into English (1559). His first wife was Archbishop Cranmer's daughter; he had a close relationship with Foxe, and was in the Tower in the Spring of 1581 for injudicious Puritan manifestations. In the next year, he helped Wolfe with copy troubles. See Harry Hoppe, "John Wolfe," The Library, Fourth Series, Vol. XIV, No. 3 (December 1933), pp. 241-289. Hoppe sees no particular case for Wolfe's Puritanism.

24 Anthony Fletcher, Tudor Rebellions (Harlow, Essex: Longman Group Ltd., 1968), p. 93. He gives no source for this.

${ }^{25}$ Anthony Munday, A Discovery (London: Edward White, 1582) fol. Bii, r. Cecil Ex., p. 5. Thomas Bell, The Anatomie of Popish Tyrannie (London: John Harrison, 1603), paragraph 3 [sic], r. Cecil implies the charge; the others make it outright.

${ }^{26}$ Bell, fol. paragraph 3, r. He also informs the reader that the pope had "assigned" the Duke of Northfolk to head the Ridolfi Plot, and had sent 150,000 crowns to finance it.

The elements which contributed to the revival of the efforts to excommunicate Elizabeth were the accession of a monk, who became Pius V (r. 1566-72), and the arrest of Mary Stuart. Hopes that the Catholic Stuart would replace the Protestant Tudor on the English throne ran high among the exiled English clergy. Coupled with this was the very different climate at the Vatican. Pius V (later St. Pius) was much more concerned with spiritual justice that temporal politics; his desire to punish heresy proved so strong that he not only thrust the machinery of Excommunication back into motion, but did not inform either Phillip of Spain or HRE Maxmillian II until the Bull was a fait accompli in February 1570.

Objections were made by concerned Catholics, especially those still in England, over the application of certain points of Canon Law and the method by which the Bull reached England (where it was posted in London by John Felton). When the Bull was not withdrawn, some of these Catholics claimed that they were not bound by its rulings due to these irregularities. See Meyer, pp. 73-87, on his second phase of the Excommunication of the English queen. Wiener adds that Pius V's influence on the rebels "cannot be determined definitively" (p. 31).

${ }^{27}$ See Wiener, pp. 32-33.

28 John Baxter, $A$ Toil for Two-legged Foxes (London: Felix Kyngston, 1600). Pope Joan appears on page 30 where, having been impregnated by a Cardinal, she gave birth in the street during a religious procession, which she later continued. She was determined, if not moral.

29 Anthony Marten, An Exhortation (London: John Windet, 1588), fol. B. Marten was the Gentlemen Sewer of the Chamber (to his death) and was made Keeper of the Library at Westminster in August 1588--reward for a job well done? DNB, Vol. XII, pp. 1155-1156. In fact, there were 16 popes between Henry VIII's accession and Elizabeth's death. 
30 Josias Nichols, The Plea of the Innocent, (no city: no printer, 1602), p. 152. This may be an illegal work.

31 Josias Nichols, p. 153.

32 Carol Wiener, Popular Anti-Catholicism in England (Cambridge: unpublished Harvard Ph.D. thesis, 1968), p. 31, hereafter cited as Thesis. She sees the bulk of the literature coming after 1579.

33 All problems encountered by the mission had been offered as reasons to avoid sending the Jesuits, but reason was swept away under pressure by Allen. Persons name is occasionally given as Parsons.

34 Smith, Treason, Chapter II "The Black Poison of Suspect," pp. 36-71.

${ }^{35}$ M. Henry Willobie, Willobie His Avisa (London: John Windet, 1594, reprint, 1966), p. 101. A wife's virtue triumphs over devious suitors. was a Puritan.

36 John Fielde, A Cavet (London: Robert Waldegrave, 1581), fol. Aiii, r. He

${ }^{37}$ Fielde, fol. Avi, r.

38 Fielde, fol. Aviii, r-v.

39 John Nichols, $A$ Declaration of the Recantation of John Nichols (London: Christopher Barker, 1581), fol. Bviii, r., note publication by queen's printer. Mr. Nichols recanted after being imprisoned again upon his return to the Continent. The DNB article (Vol. XIV, pp. 441-443), sees this as evidence that he "wholly lacked convictions." I think it quite possible that he found prison more convincing than theology.

${ }^{40}$ Read, p. 26. I found this statement most curious. Either Read is ignoring much of the contemporary literature, or had ignored the facts that did not suit his thesis. While attacks on the loyalty of Catholics becomes the focus, the questions about Catholic beliefs never ceases--see below.

${ }^{41}$ McGrath, p. 161. Leicester to Walshingham, 5 September 1582.

${ }^{42}$ Cecil, Ex., p. 6.

${ }^{43}$ Cecil, Ex., p. 29, alterations mine.

44 Cecil, Ex., p. 29.

${ }^{45}$ Christopher Muriell, An Answer Unto the Catholiques Supplication (London: R. Read, 1603), fol. A4, r. The supplication was to the new king, James I. 
46 Andrew Willet, $A$ Catholicon (Cambridge: John Legat, 1602), fol. B5, r., by my count, emphasis mine. Hereafter Cath.

47 Wiener, Thesis, p. 15.

48 Wiener, Thesis, p. 5.

49 Anthony Munday, $A$ Breefe Answer (London: John Charlewood, 1582). The English Roymayn Life (London: Charlewood, 1582). He may have been a spy at the seminary; Munday later worked for Topcliffe and was sacked for picking up stray money at the houses he searched. He was also a rival of Ben Johnson's. DNB, XII, p. 1194.

50 Wiener, Thesis, p. 5.

51 George Whetstone, The Censure of a Loyall Subject (London: Richard Jones, 1587). See also the DNB article, Vol. XX, pp. 1360-64.

52 Read, p. 29.

53 Hofstadter, p. 21.

54 J. Payne Collier, ed., Broadside Blackletter Ballads (New York: Burt Franklin, 1868; 1968), p. 58. "A Warning to All False Traitors," 1588, by an unknown author after the Babington Plot.

55 Thomas Lupton, A Persuaision From Papistrie (London: Henry Bynneman, 1581), fol., 1A, ver.

56 John Bale, trans., John Studley, The Pagent of Popes (London: n. pub., 1574), original Latin 1554, fol. biii, r. The translator's epistle to the reader. The dedication was to Thomas Radcliffe, Third Earl of Sussex.

57 Lewys Evans, The Hateful Hypocrisie (London: Thomas Purfoote), fol. Evii, ver. (my count). Evans was an apostate Catholic.

58 Lupton, fol. aii, r.

59 Baxter, pp. 37-38. He also compares the danger to that of ivy creeping up an oak.

60 Andrew Willet, Tetrastylon Papisticum (London: Robert Robinson, 1593), fol. A6, ver., hereafter Tetra. This is sort of a Protestant Sic et Non, wherein the author proves his point by setting conflicting passages from Catholic works next to each other. The statement was directed at papists, but applies equally to Protestants. 
${ }^{62}$ Baxter, p. 40.

63 Baxter, p. 135.

${ }^{64}$ Baxter, pp. 135-148.

${ }^{65}$ Baxter, pp. 149-175.

${ }^{66}$ Baxter, pp. 210.

${ }^{67}$ McGrath, p. 1.

${ }^{68}$ David Loades, The Tudor Court (Totowa, NJ: Barnes \& Noble, 1987), p. 153, the quote dates from 1573.

${ }^{69}$ Willett, Cath., fol. B5, r. A catholicon is a universal remedy; I am sure that the pun was intended.

70 Wiener, Thesis, p. 13.

71 Jos. Nichols, p. 151.

72 Haller, p. 91.

${ }^{73}$ Willet, Cath., fol. B5, ver. An interesting discussion of labels may be found in Thomas Clancy's "Papist--Protestant--Puritan," Recusant History, Vol. 13, No. 4 (October 1976), pp. 227-253.

${ }^{74}$ William Lightfoot, The Complaint of England (London: John Wolfe, 1587).

${ }^{75}$ It is for this reason that title pages carried the location of the printer's shop. On Lightfoot's we learn that Wolfe was at "Distaffe lane, neare the signe of the Castle."

${ }^{76}$ [William Cecil] A Letter to Mendoza (London: Thomas Vautrollier, 1588), fol. Aiii, r. The pamphlet was in the guise of a letter left by a priest, Richard Liegh, and discovered after his flight.

${ }^{77}$ Hofstadter, p. 25. I have exchanged "nation" for "United States."

78 Wiener, p. 28.

${ }^{79}$ Fielde, fol. Ciii, r. A reply to charges of harshness on the part of the government in its treatment of Catholics.

${ }^{80}$ Peter Holmes, Resistance and Compromise (Cambridge: CUP, 1982), p. 189. It is worth noting that when given the chance to take such an oath under James I, the Appellants refused. 
${ }^{81}$ Norton used this reasoning to explain why there had been no new books from Louvin--they were ticking away all over England soon to explode into rebellion. fol. Biiii, r.

${ }^{82}$ Norton, fol. Biiii, ver.

${ }^{83}$ Smith, p. 169 . Words addressed to Thomas More at his trial, indicative of the suspicious nature of the time. 


\section{CHAPTER III}

\section{ROGUISH PEDLARS OF WHORISH MERCHANDICE}

[The Jesuits and seminary priests are] roguish pedlars of whorish merchandice; whose drift is nothing else, but to reconcile simple people to the obedience of the Pope, to powre into their harts pestilent opinions against her Majestie, and the lawes of this Realme, to sound the secrets of inward intensions, to set discontented harts on fires with the flames of rebellion, to feede foolish humors with varie hopes of alteration: in the meane while, teaching rebelles to carry countenances friendly to conformitie . . . els to what end serveth that posie sent from ould Rainard to his cursed cubs, da mihi cor tuum \& sufficit. $^{l}$

That the hand of God was protecting the nation was a sign not only of His favor with the Civil organization, but with the religious settlement as well. If the specifics of doctrinal differences between Protestants and Catholics remained obscure for the bulk of the population, the core was not. Protestants had reclaimed God's truth from centuries of Catholic obfuscation and deception, and were marching to glory under His banner. With truth over their heads, the irritations of Catholicism should have been minor and transitory, but promised victory in heaven can at times be small comfort to a nation faced with the problems of earthly politics and conflict. As we have seen evidenced in contemporary pamphlets, earthly victory did not appear as certain as it might have; if the Catholics held no truth, they did appear to have power enough to be a real threat. The battle had taken on almost Manichean proportions.

"But in vaine doe wee withstand them with out tounges and pennes, if the Christian Magistrates doe not put to their helping hand,"2 lamented one writer; the 
crown took such admonitions to heart. Although the battle against the papists was "clearly" over the question of obedience to the prince, the tension over religion would not go away. Again and again readers were reminded that whatever happened to naughty papists, it was not papal supremacy in doctrine, or any tenants of faith which had forced the actions, "for none of these points have any persons been prosecuted with charge of treason or in danger of life, ${ }^{, 3}$ and in truth:

all the infamious libels lately published abroad in sundry languages, and the slanderous reports made in other prince's courts of a multitude of persons to have been of late put to torments and death only for profession of the Catholic religion, and not for matters of state against the Queen's Majesty are false and shameless and published to the maintenance of traitors and rebels. ${ }^{4}$

And yet, there is a rather hollow ring to these protestations of secular clemency. When one is torturing and executing priests, it is hard to maintain that the question of faith does not enter into the process.

For a people who were constantly reminded of the martyrs of Smithfield, the spectacle of a man--even a papist--being hung, drawn, and quartered while proclaiming his faith (even if it were false), must have had unsettling associations. For all the rhetoric which assured them that doctrinal differences were not the issue, it was clear to any who cared to look that religion was precisely the problem. While much of the vehemence with which the attacks were made upon Catholics in the pamphlets grows out of the fears for the nation's survival, an underlying component of that anxiety results from the attempt to prove that England was not persecuting Catholics for their religion--when that was exactly what they were doing.

The queen's subjects may continue to be Catholics so long as they pretend to be Protestants, and to live as Protestants, and to use the new rites as though they are Protestants. They do not need to believe anything of what they profess to believe. 5 
The Elizabethan Protestants would have objected that men certainly were expected to believe what they professed, but would probably have added that Catholics could not be trusted even if they did attend church:

Of Papists there be three kinds. (1) The Open Papist which dwelleth among us and forsake our Communion.... The second sort are fleeing Papists, which flee over the sea and return again ... with traiterous meaning ... to steal away the hearts of subjects from the Prince and magistrates \& ... The third kind . . . is the cunning Papists wich can hide himself under colour of loyality and obedience to the laws, and will needs be accounted a faithful, true and good subject, and yet carrieth in his bosom in effect the same persuasion that the others do and for fear of danger or discredit, they are contented to obey the law. ${ }^{6}$

Of conscience there could be no admitting; of earnestness no belief, they were but blinds and shows.

Yet it is no easy task to toss out several hundred years of history without a backward glance. How did one explain over a thousands years of such error? In the battles which raged between the pamphleteers, this was a popular question. Catholics, of course, maintained that the history of the church demonstrated that they had always been right and the long survival of the Roman See proved that; Protestants were merely indulging in novelty, and threatening the divinely ordered unity which Europe had enjoyed. Some went so far as to call the changes in English church government a Machiavellian plot devised by Cecil and Bacon. ${ }^{7}$

Besides the basic Protestant emphasis upon scriptural authority over papal, the main thrust of efforts (at least in the pamphlets which are more specifically secular), was to couch the battle in similar terms to those used over the question of loyalty: deception and perfidy. Not only the basis of papal authority, but the term "catholic" became points of argument, both the meaning of the word and the right to use it. Puritans, having proven (at least to their own satisfaction), their right to be considered 
the true Christian church, were therefore the people entitled to be called "Catholics," those now using the term being mere papists. Robert Abbot pointed out such misuse by Romish priests who had "for a time used the name Catholic church, as a fray-bug to terrifie al men for speaking against them." ${ }^{8}$ The reasons such men had gone to Continental seminaries in the first place showed they had no real concern for truth and Christianity:

I thinke it not wisedome, in these dayes to flee from Englande to a forraine realme, I think it no godliness to leave God, \& to leane to Antichrist. Shall we flee from light to darkness from the Gospell to vayne gloses, from trueth to falsehoode, from faith to infidelitie, from religion to superstition? God forbidde. ${ }^{9}$

The safety to the realm depended on conformity, other nations no less than England demanded such:

[Ask of the Catholics i]f ever they dyd reade, heare or knowe of anie one King or Queene, that dyd with greater mildness of lenitie tollerate or suffer within his or her dominion a sect of religion oppsite to the lawes by him or her establyshed, especiallye the same having sundrye times rebelliously attempted against their crown, state, and dignitie. ${ }^{10}$

Jean Gerson had warned that, unlike philosophy (which it surpassed), religious teaching had revealed boundaries, and it was clear that no teaching should go outside these boundaries. ${ }^{11}$ Protestants and Catholics agreed upon this, but were at an impasse to establish where these revealed boundaries lay.

The polemicists depended not only (nor indeed very often) on scriptural authority, but concentrated upon the nature of Catholic rites. To disprove the religious nature of Roman church would strip away the meaning and purpose they were said to embody; without that meaning they were but superstitious nonsense, and no true evidences of faith.

Thus our adversaries of the Popish religion (which in deed is no religion, but mere superstition) have subitillie sought to undermine us, crying out 
against us, that wee are lyers, Idolaters, blasphemers, and such like, which are titles and epithetes fitter and more proper to themselves. ${ }^{12}$

As Read points out, the Catholics were referred to as "papists and atheists in the same breath," and, as a standard propaganda method, their detractors would accuse them of "pretended conscience"; then attack their motives as "anti-christian, vicious or subversive. ${ }^{n 3}$ In the same way, they were vilified for pretended loyalty to the crown, Catholics were attacked for pretended religion and loyalty to the one true God.

Evans and Fulke both refer to the "synagogue" which is the Roman church, ${ }^{14}$ to which Baxter adds that their doctrine shows that the Catholic church is "Heathenenish, [and] Turkish" as well, ${ }^{15}$ he then compares the pope to Mohammed. ${ }^{16}$ Catholicism is built "not upon the doctrines of the Prophets and Apostiles," but rather founded on a bit of scripture (to fool the unwary), Patristic writings (which Rome of course acknowledged), the Caballa, the Koran, Ovid (The Amores?), and Aristotle. ${ }^{17}$ Willet's Tetrastylon outlined the four pillars of Catholicism:

1. "raylings, slanders, forgeries, untruths";

2. "blasphemies, flat contradictions to scripture, hereises, absurdities";

3. "loose arguments, weak solutions, subtill distinctions"; and

4. "the repugnant opinions of New Papists. ${ }^{18}$

Abbot concentrated upon particular points of error, but as a theologian he could be expected to be more specific. Justification by faith, the nature of communion, Transubstantiation, Assumption of the Virgin, the Apographa, and the "mangling and martyring" of Patristic writings (rather than their use), were the things which most distressed him. ${ }^{19}$ 
The mass itself was one of the worst elements of the heretical sect, not only in its obscuring of the elements of true Christianity, but in the danger it posed to the simple souls which might be dazzled and drawn away from proper worship:

Gods worship is in spirit and trueth; and poperies is in gold and silver \& pearle, and crucifixes, and Agnus deis, all for the eye, and to snare the heart of carnall man, bewitching it with so great gilstering of the painted harlot. ${ }^{20}$

Apostate John Nichols warned the unwary that while he had been a papist he "neither heard the worde of God syncerely taught, the Sacraments rightly administered, nor the Name of God duely called upon. ${ }^{21}$ William Perkins, yet another who had seen the error in his former church offered: "[An] advertisement to all favourers of the Romane religion, shewing that the said religion is against Catholike principles and grounds of the Catechisme."22 The true church is always under attack, Baxter warned, and those who believe that the outward calm and quiet to be the truth are but fools. ${ }^{23}$

Priestly functions, besides the puffery of the mass, are differentiated from those of the men who minister the Gospel to sincere Christians. Whether they are Baxter's "Jesuiticall cubbes, and extravagant Foxe-priests," ${ }^{24}$ or Evans's deceptively clothed wolves who engage in cursing, harming true Christians, false teaching, fornication, sodomy, adultery, hypocracy, and superstition. ${ }^{25}$ They care not for the souls of the men and women they counsel, but seek merely to harden their bodies to the task of rebellion: "Papistrie hath no looking beyond this world, but is determined within worldly hopes, and therefore their devises must be thought to tend to worldly politike endes. ${ }^{26}$

Tyndale had warned that the confessional was nothing more than the mechanism by which the Roman church kept an ear on the musings of the people, so 
as to excommunicate those who protested against them. ${ }^{27}$ By Elizabeth's time, however, their methods had been adapted to the new situation in England, and had new aims:

They are trained to conference and secrete consultation to make shift for their soules by ghostly counsell, and this their Confession, wherein many traiterous devises are agreed upon. ${ }^{28}$

Papists might protest that meeting together for mass was but for their souls' sake, and meant no harm to their neighbors; that, of course, was also concealment of purpose;

It is not unknown how for such reconcilements assemblies have been suspiciously made, substitutes have been duputed, and the like by many exercised, to crepe into deceaved subjects hartes and draw them to bewailing of their supposed miseries, and to a desire of returning to the fanciful superstitions of Rome. ${ }^{29}$

Lupton warned, too, that the mass was a grave danger to the realm, if it were allowed to return to England "then our propertie and peace would be turned into adversitie and warres." ${ }^{\text {30 }}$ Canonization went to those "that can bring most souls to confusion," Baxter assured his readers. ${ }^{31}$

The queen's keeping of a crucifix in her chapel inspired a brief flurry of pamphlets speculating on her true feelings in the matter of ceremony (a question still raised in modern writing), horrifying her guardians of Truth. It is a mark of the differences between the sixteenth and later centuries, as well as the regard in which the queen was held, that none saw this as evidence of the queen's involvement in papal plotting. For the modern author working in the paranoid style, involvement of the highest persons of the government, even the highest, is not too far to reach when placing blame. Indeed, it would not be even a century later when the crown itself would be the target for the responsibility of the nation's ills. Yet in Elizabeth's time the failings remained those of advisors, and any slip on the part of the monarch could 
be explained by asserting that things did not mean what they appeared to mean, or that the full impact of the action would shortly become clear, and the remedy made.

While the Protestant writers used the crucifix as a symbol of the superstitious nature of Catholicism, they were not content to leave it at that. In a Neoplatonic world things must have meanings; they are all types of reflections of something "real" in the mind of God, so--having removed the religious meaning from the traditional symbols of Catholicism--the anti-papists were free to assign their own meanings to them. Since all things related to the Romish crew were either covertly or overtly evil, even the cross could have sinister uses. Accustomed to thinking in terms of armorial devises, the answer was clear, these things were badges of the army of the Antichrist:

I know that some of you weare the mark of the beast, as a cross, an agnus $d e i$, or some character of the babilouishs [sic] whore, whereby you hope you shall be mark from Hugenotes, if that day should come that you look for. ${ }^{32}$

Such badges were, of course, distributed at the mass, which was famous for "the deliverie of badges and token . . . as it were for markes of faction. ${ }^{133}$ Importation of the agnus dei, crucifixes and like items were forbidden by law in 1571 , a year after the importation of papal bulis was first made offense:

[I]f any person or persons shall at any time after the first day of July [import] . . . any token or tokens, thing or things, called by the name of an Angus Dei, or any crosses, pictures, beads or such like vain and superstitious things from the bishop or see of Rome . . . shall incur into the dangers, penalties, pains, and forfeitures ordained and provided by the statute of praemunire and provision. ${ }^{34}$

Thus when a seizure of "certain bookes and other unlawful thinges," made at Greenwich is reported, we may be reasonably certain that the other things muse have been these marks of faction. ${ }^{35}$ 
Relying on the efficacy of saintly intervention was an equally dubious practice. Burton's examination of melancholy looks at the questionable notion of seeking the aid of saints when one is in the throes of the disease. Of course, such an idea is discarded outright, since the good Protestant should "seek to God alone" for aid. ${ }^{36}$ Tales of miracles, he assures the reader, are nonsense and fakery. An account of such goings on had recently come to Burton's attention:

A Declaration of egregious Popish Imposture, to withdraw the hearts of religious men under the pretense of casting out of Devils, practiced by Father Edmunds, alias Weston, a Jesuit, and divers Romish Priests, his wicked associates, with the several parties' names, confessions, examinations, \&e [sic] which were pretended to be possessed. But these are ordinary tricks only to get opinion and money, mere impostures. ${ }^{37}$

Done by proper Protestant ministers in the next century, such casting out of devils would, or course, be God's work.

Catholicism was frequently described as a "mingle-mangle" or "hotch-potch" religion, when it was called a religion at all. Like civil order, the religious order was in constant danger of contamination by the presence of the Pope's forces. Perkins warned that it was impossible for both to exist in England, as impossible as the mixing of light and dark. ${ }^{38}$ The protection of the Church of England was as important a task as guarding the shores, and complaints of a few papists must not stand in the way. Fielde warned his dedicatee, Dudley, of one such protest from a former papist friend who approached him:

[I]n great greefe, for that to your honor [sic], I have insinuated the Papists to be enemies to God, and to her royall majestie. This he saith, I have done to excite youre honour to persecution. The truth is, I did it to youre honour, because, that as God hath set you in cheefe place over his church, so you and all the rest of your calling, might watch against such enemies, and discharge that trust he hath committed unto you, both to stoppe from further undermining the Church of god ... [and] for the preservation of the Queene. ${ }^{39}$ 
Indeed, although the secular and religious were spoken of separately, on occasion, it is clear from Fielde's admonition that these are but facets of the same problem, the queen's preservation and that of the church were as firmly linked as the monarch's survival and the nation's preservation. Baxter's "Maxima" leaves no doubt on this point: "As Poperie and treatcherie goe hand in hand, whilest Poperie is kept under; so Poperie and crueltie are companions unseparable, if once Poperie get the upper hand." ${ }^{40}$ The papists are traitors to the nation, and enemies of the true Christian church. The Jesuits and seminary priests come in disguise both to hide their identities and their purposes. All is set, and but lies in wait for the proper moment. The crucifixes will be brought out, the papal forces will hit the beaches of England, and the men and women who protested their innocence and loyalty will throw off their pretended consciences, and the end will be at hand:

[The Jesuits and seminary priests] have of late years come and been sent, and daily do come and are sent not only to withdraw her highness's subjects from their due obedience to her majesty, but also to stir up and move sedition, rebellion, and open hostility within the same her highness's realms and dominions, to the great endangering of the safety of her most royal person, and to the utter ruin, desolation, and overthrow of the whole realm, if the same not the sooner by some good means be forseen and prevented. ${ }^{41}$

Christopher Murriell confirmed the tie: "For I dare boldly affirme that they cannot proove that any one received the sentence of death onely for professing the Romish religion, except treason were thereunto also annexed."42

God's creation has order and reason, because it is of God. Catholics offend against the order of His universe by obeying the pope in some things rather than obeying their divinely sent monarch in all. They offend against the reason of His creation by clinging to the lies and wickedness of the Roman See. Thus their threat 
to the universe is doubly clear, and their punishment at the hands of Christians doubly deserved. It is God's will. 
NOTES:

\section{CHAPTER III}

${ }^{1}$ Baxter, p. 16. Latin: "from my heart to your's and the foundation is layed," my translation.

${ }^{2}$ Francis Bunny, Truth and Falsehood (London: Valentine Sims, 1595), fol. $\mathrm{A} 2$, ver. The author was the brother of Edmund Bunny.

${ }^{3}$ Cecil, Ex., p. 13.

${ }^{4}$ Cecil, Ex., p. 20.

${ }^{5}$ McGrath, quoting Philip Hughes, p. 55.

${ }^{6}$ Clancy, p. 229, his elisions, quoting Bishop Thomas Cooper (d. 1594).

${ }^{7}$ See John Leslie, $A$ Treatise of Treasons against $Q$. Elizabeth (n.c.: n.p., 1572). Bacon and Cecil are all but named. The charge was apparently current among the Catholic exiles, see Bayne, pp. 782-795.

${ }^{8}$ Robert Abbot, $A$ Mirror of Popish Subtilities (London: Thomas Creede, 1594), fol. A2, ver.

9 Lewys Evans, The Hateful Hypocracie (London: Thomas Purfoote, 1570), fol. Aiiii, ver. He was another apostate Catholic.

${ }^{10}$ Sir Lewis Lewkenor, A Discourse of the Usage of the English Fugitives (London: Thomas Scarlet, 1595), fol. F1, r.

11 Bouwsma, p. 232. Jean Gerson, 1363-1429.

12 Willet, Tetra., fol. A6, ver., by my count.

13 Read, p. 215.

${ }^{14}$ Evans, Av, r. Fulke, see Milward, p. 13.

${ }^{15}$ Baxter, p. 25.

${ }^{16}$ Baxter, p. 91.

${ }^{17}$ Baxter, p. 26.

${ }^{18}$ Willet, Tetra., title page. The new papists were the freshly arrived Jesuits and seminarians. 
19 Abbot, passim.

20 Wiener, pp. 44-45.

21 John Nichols, Vol. Avii, ver.

22 William Perkins, A reformed Catholike (Cambridge: John Legat, 1598), title page.

${ }^{23}$ Baxter, pp. 1-4. He points to the tribulations of the Jews in the Old Testament, and Jesus in the New as examples of the trials which the Protestants are suffering even now.

${ }^{24}$ Baxter, p. 80.

${ }^{25}$ Evans, fol. Bii, ver.

${ }^{26}$ Norton, fol. Biii, ver.

${ }^{27}$ Smith, p. 61. They lurked, he warned, "in every great man's house, and in every tavern and ale house." An early modern Big Brother, if you will.

${ }^{28}$ Norton, fol. Biii, r.

${ }^{29}$ Norton, fol. Bii, r.

${ }^{30}$ Lupton, fol. Div, ver., by my count.

31 Baxter, p. 16.

32 Baxter, p. 19.

${ }^{33}$ Norton, fol. Bii, r.

34 Elton, p. 421.13 Eliz. I, c. 2 (1571).

35 Arber II, p. 806. Report of 5 June 1586, to Digby. The books were turned over to the local bishop. Source: Council register, Eliz., Vol. VI, fol. 199.

${ }^{36}$ Robert Burton, The Anatomy of Melancholy (New York: Tudor Publishing Co., 1927), pp. $386-388$.

37 Burton, p. 388.

38 Perkins, 2 [sic], r.

${ }^{39}$ Fielde, fol. Aii, r. and ver. 
${ }^{40}$ Baxter, title page.

${ }^{41}$ Henry Gee and Wm. John Hardy, Documents Illustrative of English Church History (London and New York: Macmillian and Co., 1896), p. 485.1585 Act Against Jesuits and Seminary Priests.

${ }^{42}$ Murriell, fol. A2, r. 


\section{CHAPTER IV}

\section{CONCLUSION:}

\section{NO INNOCENT WAS TORMENTED}

So as it was first assured that no innocent was any time tormented. And the rack was never used to wring out confessions at adventure upon uncertainties, in which it might be possible that an innocent in that case might be racked. ${ }^{1}$

If there is one criterion which typifies human society, it is the drive for order.

On one level it is nothing more than the necessary component for a group's survival, whether it is a "tribe" living under nomadic conditions or a highly centralized bureaucratic system, some plan or set of rules must govern so that the group may function and survive. This basic survival system becomes layered with intention and meanings over time, until what was a mechanism becomes a belief system.

Neoplatonism's development and acceptance gave the Europeans a model with which they could explain their own society, its means of functioning and its ends. The Chain of Being provided a place for everyone, and a reason for their being there. It outlined the function of each level and provided parallels by which the system could be examined and explained. For Christians, it was a primary understanding that this order was created, as was all else, by their God, who in this act of creation provided the ultimate meaning and purpose for its existence. Order had been made from chaos, and to chaos it would return if the order were not maintained.

[Chaos] to an Elizabethan ... meant the cosmic anarchy before creation and the wholesale dissolution that would result if the pressure of Providence relaxed and allowed the law of nature to cease functioning. ${ }^{2}$ 
It is not hard for us to understand the fears of sixteenth century men and women, who believed so strongly in a real order which had sustained them and their parents, an order which seemed to be threatened on all fronts. Every generation has an idealized past from which their present has declined, and which passing they lament. It is only recently that scientists have begun to consider a theory of chaos, and muse on the randomness of what we had believed to be a universe governed by fixed laws of physics. Yet aside from scientific theory, people feel a need to have reasons and explanations for the situations in which they find themselves, and the events and forces that brought them there.

There is much which seems familiar to a citizen of the twentieth century, when viewing the sixteenth. On every side truths which seemed to hold the universe together were being challenged, and to many the elements which might replace them seem unacceptable, or nonexistent. So, it seems, was the dubious prospect of settlement in the reign of Elizabeth I. The turmoil of the previous Tudor monarchies had, for the English, put the events of Elizabeth's reign into a context which made every conflict seem to bode the end of the realm.

The dangers presented by the printing press became clearer only with the gradual development and expansion of the printing trade. The increasing demand for ideas and information provided an opportunity for the crown to convey its wishes and commands, but also opened a new venue for all sorts of notions that the crown would find distasteful or threatening. If we accept the assertion that none wished to look into citizens' hearts, it is clear, nonetheless that their tongues, and bookshelves, were a matter for grave concern. 
The question of the extent of literacy is a difficult, and perhaps insoluble one. Existing data are problematic, and tend to indicate more about the seventeenth century than the sixteenth. ${ }^{3}$ The general impression of the development from the 1530 s to the Civil War (and beyond) of a gradually increasing incidence of literacy "is broad, vague, and uncontroversial." Attempts to use quantitative methods to clarify that impression are being increasingly employed. Researchers admit that the methods available are less than perfect. The use of a signature has been identified as the most universal and carrying the least class bias (as opposed to wills, for example), and useful from region to region..$^{5}$ However, there are two important weaknesses in the use of signatures: Reading was taught before writing (not together as today), as they are separate skills-thus a person might well be able to read and yet unable to write; and (2) even when writing was taught, the signature was not an important consideration and might, due to the difficulties of "properly" spelling English names, be discouraged altogether in the interest of concentrating on the broader applications. ${ }^{6}$ Yet it remains a more robust measure than the will, which favors more affluent males and virtually eliminates any mention of women. Such testaments are also unreliable in that books were not always considered important enough to mention at all, and not often counted or titles listed if they were. Bibles, often several, are known to have been owned by families who could not read them. ${ }^{7}$

Cressy, F. J. Levy, and Joyce Youings all use the ability to sign one's name as a proxy for their estimates of literacy. For Norwhich gentry in the period 1590-1700, Levy estimates a 98 percent rate; ${ }^{8}$ Youings gives sixteenth century rates for the lower orders as a possible one in ten husbandmen (with probable higher rates for craftsmen), and perhaps as high as 40 percent for the better sort of farmer. ${ }^{9}$ Overall, Cressy 
assumes than two-thirds of the men, and nine in ten of the women in England could not sign their names by the time of the Civil War. ${ }^{10}$ Class and geography would effect the rates, in that literacy would be higher among the more wealthy classes, and closer to urban centers where more schools would be available. ${ }^{11}$ Thus, one might reasonably expect London citizens to have higher rates of at least reading ability at all levels of society.

Ideas do not necessarily begin, or end, with print, even today. Anti-Catholic rhetoric did not spring full grown from the presses, but must have reflected ideas and fears already existing in the people's minds, or at least found a ready place there. If printers were willing to finance an author's travels (with a view toward publishing the resulting work), or literary men strapped for cash, and seeking access to the purses of the mighty, would see this genre as a means to their financial end, the possibilities must have appeared worth the risk. Pamphleteers of all persuasions sought the chance to change perceptions, and action, by turning to print as the most effective means to present their message. For Catholics, it was the only way by which their voice could be heard with even a minimum of safety. For Puritans, it was a chance to disassociate themselves from the danger represented by the papists--their nonconformity offered as a bulwark of Protestant resistance to the Babylonian Whore. To the crown, and the Anglican majority, the press provided a means by which accusations could be answered, plots unmasked, and policies illuminated.

Print was the one battleground upon which they could all meet to decide the future of the nation and the terminus for its souls. In the attempt to control the field, the government sought to prevent access. Although they were unable to keep the opposing forces from setting up their standards, official actions did limit the 
effectiveness of their enemies' vollies, as well as defining who was firing, and why. The survival of the realm demanded that these challenges be treated as equally perilous. The disinclination to attend Anglican service was as fraught with doom as an armed rebellion.

Regnans in excelcis provided two elements which had previously been missing from the struggle for England. First, it clarified the position of the Holy See, vis-à-vis Elizabeth's right to rule as an anointed servant of God's will on earth, putting the situation on a firm, if difficult, footing. Secondly, it gave the crown, and all those who saw themselves as its ardent defenders, a neatly packaged cause for their ills. The solution, however, proved to be both more, and less, than it had first appeared. The new situation did offer the scapegoat upon which all evil could be heaped:

[L]ike butchers curres you prayse her clemencie and mercy, and yet you charge her majesties government with unipeakable [sic] outrage and cruelty. ${ }^{12}$

My purpose in this pamphlet is rather to discover the wickedness of English Italionates, then to dispute against the willful obstinancie of any Catholic champion. ${ }^{13}$

Yet the perception was that the Roman Catholics were a totally unified, single-minded force which would stop at nothing to reach their goals, and might very well emerge victorious in the end:

[Englishmen should] take heede and beware of their mischievous broode of caterpillars, for they speake so devoutly, looke so smoothly, and write with such counterfeited gravitie and holiness, that it is hard for any man to eschue their deadly baits, unless he thoroughly doo first know their trechery. ${ }^{14}$

We strive in vain ... we hoped that these papisticall priests dying, all papistry should have died and ended with them, but this brood [seminaries and Jesuits] will never be rooted out: it is impossible ... to extirpate the papisticall faith out of the land. ${ }^{15}$ 
Even if we cannot be certain of readership, it is possible to see some of the consequences of the embracing of anti-Catholicism by the English. Rumors of Catholic actions were increasingly sufficient to provoke mass action, as early as 1596 there was a panic in Sussex "over a rumoured Catholic uprising," ${ }^{16}$ as there was in Hampshire and Monmouth in 1605, "both independently of the Gunpower Plot."17 The Royalist army banned Catholics from service during the Civil War, due to the concern of the king's advisors, who "[h]ad ample cause for anxiety: concern over the loyalty of Catholics was deep and widespread."18 Although there was a period of calm in the 1630 s, between 1640 and 1642 there were panics in the nation's five largest cities over imagined conspiracies by the papists. ${ }^{19}$ That the weakened, disillusioned Catholics, whose recusancy had dropped to between two and five percent by the $1630 \mathrm{~s},{ }^{20}$ could still inspire such potent fear, speaks to the successes of the anti-Catholic propaganda, whether from the pulpit, street rumor, broadside ballads, or pamphlets.

As late as the nineteenth century, when the Whigs had committed themselves to Catholic emancipation, the ghostly army of pamphleteers were pulled from their rest to enter the battle against such hazardous nonsense, John Foxe, the most prominent among them.

Even Macaulay, the great Whig historian, writing at the height of Victorian self-confidence in technological progress, and himself sure that Catholicism stood for medieval superstition, could not help imagining a remote future in which London was in ruins while Papal Rome stood intact and triumphant. ${ }^{21}$

Even the rhetoric from nineteenth century America has the ring of its Elizabethan predecessors. S.F.B. Morse (of code fame) published a warning to his countrymen of the questionable motives which must lurk behind Austria's sending of Jesuit missionaries to their shores: "A conspiracy exists ... its plans are already in operation 
... we are attacked in a vulnerable quarter which cannot be defended by our ships, our forts, or our armies." 22

The legacy of English anti-Catholicism is anxiety, fear, panic, and hatred. The legacy of the pamphleteers is a standardized, often clichéd, rhetorical form which served to cast what might have been a merely uncomfortable situation into a fight for the salvation of England as it stood in the path of the Catholic Juggernaut. The unity which the English felt in the face of the source of their troubles can hardly compensate for the anxiety over their possible fate. Yet hindsight is the luxury of the historian. For the English men and women under Elizabeth's rule, the identification of the cause of their many troubles, the one element which most threatened them, provided gleeful relief. Now they knew why there were rebellions against the rightful monarch, and they could take action to stop papists from achieving the Antichrist's ends.

To the Englishmen of the sixteenth century the structure of the universe seemed clear and logical. God had created and ordered it in such a way that everyone and everything had a specific, permanent place which carried with it appropriate duties and responsibilities. Primary among these requirements was obedience to one's betters, up the Chain of Being, to God. Unity demanded uniformity; obedience held the universe together. Within this context, the excommunication of Elizabeth Tudor in 1570 both redefined and intensified the strain between the crown and the various religious groups in the realm. Catholics had become traitors, or at least potential traitors, with the stroke of a papal pen.

The printing press, which had come to England in 1467, had become increasingly important as a tool to explain and, if possible, foster support for, crown 
opinion. Because of the regulatory system which had evolved since the introduction of print, it is possible to determine those pamphlets which were legal, and therefore either reflected attitudes officials wished to encourage, or were at least willing to allow. While the printing of pamphlets containing unacceptable views could not be stopped, the system was at least able to force them underground. Legal and illegal works vied to win readers to their side in the struggle for support; legal pamphlets present the governments definition and interpretation of the problems caused by the presence of the native Catholics.

Theses pamphlets are examples of what Richard Hofstadter has called "the paranoid style," as a literary rather than clinical description. The style is pervasive throughout the genre and is characterized by an over estimation of the enemy's power, and an almost obsessive concern with plots real and imagined. The anti-papist literature displays both the confidence that God stands with the Protestants and the fear of Catholic victory.

The aim of the pamphlets is, in the main, to warn of the danger presented by the Catholic presence, and to reinforce the crown's assertion that any anti-Catholic action is taken to prevent or punish treason. Examples of Catholic perfidy are rehearsed, and aims and methods explained with an almost hysterical determination. Having seen Mary's burning of Protestant heretics at Smithfield, the insistence that treason and not theology is the focus of concern is an attempt to convince the writer as well as the reader.

Even in those works which have a more political than theological agenda, however, attacks on papist theology appear. In the context of these pamphlets the attacks are not merely repetitions of the general Protestant assault on Catholic 
doctrine, but can be seen as an attempt to reassure themselves that, not only are Catholics not being persecuted for their religious beliefs, but they have no true religion for which to be persecuted.

The arguments, charges, and language of these pamphlets would continue to characterize the repression of Catholics, and the necessity for that repression, well into the nineteenth century--many charges surviving to the present day in virtually the same language. The anti-Catholic mind set developed between 1570 and the queen's death in 1603 became part of the English identity, and in certain quarters continues to define the Protestant/Catholic interaction.

If there is any revolution in English history, it is here. In one generation, a portion of English society had gone from a group misguided in their method of religious devotion to a vicious pack of wolves (or foxes) thirsting after the lifeblood of the nation. The battle was so clear, the roles so firmly cast, that the picture of Catholic perfidy was embraced and made a monument. We live in the long shadow of that monument. The myths of the past, and actions they inspired, continue to play a grim part of present-day British politics, with bloody result.

Thowghe Poperie wrought a greate while agoe, That Percie provoked king Harry to frowne. Yet who would have thought there were anymoe, That would not yet be trew to the Crowne.

$$
[. .]
$$

And though you do greete her like Traytours with treason, To whom you owe honour with cappe and knee downe.

I am sure that Sainet Peter will say it is reason, to rule ye that will not be true to the Crown. ${ }^{23}$ 
NOTES:

CHAPTER IV

${ }^{1}$ A declaration of the favorable dealing ([London: no printer], 1583), p. 43. This pamphlet had been attributed to both Cecil and Norton. I am inclined to think it is too concise in presentation and lacks the rambling nature of Cecil's style.

2 Tillyard, p. 16.

${ }^{3}$ On the problems of the data see David Cressy, Literacy and Social Order (Cambridge: CUP, 1980), pp. 19-61; also Arthur J. Slavin, The Tudor Age and Beyond (Malabar, FL: Robert E. Krieger Publishing Co., 1987), pp. 189-208.

\footnotetext{
${ }^{4}$ Cressy, p. 53.

5 Slavin, p. 197.

${ }^{6}$ Cressy, p. 25.

7 Cressy, p. 49.
}

${ }^{8}$ F. J. Levy, "How Information Spread Among the Gentry, 1550-1640," The Journal of British Studies, Vol. XXI, No. 2 (Spring 1982), p. 12.

9 Joyce Youings, Sixteenth-Century England (Harmondsworth: Penguin Books, 1984), pp. 120-121. She gives no source for these estimates.

${ }^{10}$ Cressy, p. 2.

${ }^{11}$ Cressy, data tables, pp. 191-201.

12 Field, fol. Av, r.

13 Baxter, p. 40.

14 Lewkenore, fol. Ev, r.

15 Wiener, quoting William Leigh's Great Britaines, Great Deliverance (1606), p. 50, additions and elisions hers. This comes, of course, after the Gunpower Plot and after the period studied here, but does reflect the legacy of the genre.

${ }^{16}$ Robin Clifton, "The Popular Fear of Catholics During the English Revolution," Past and Present, No. 52 (August 1971), p. 24, source Landsdowne Mss., Burghley Papers, 82 fol. 013.

17 Clifton, p. 24.

${ }^{18}$ Clifton, p. 25. 
${ }^{19}$ Clifton, p. 25. Huntington, Durham, and Westmoreland alone had no such panics; Clifton does not try to explain.

${ }^{20}$ Clifton, p. 34, the former figure is his own, the latter from a papal agent in the 1630 s.

21 J. C. H. Aveling, The Handle and the Ax (London: Blond and Briggs, Itd., 1976), p. 10.

22 Hofstadter, p. 19, quoting Morse's Foreign Conspiracy Against the Liberties of the United States (1835), elisions his. The author was unsure as to the exact purpose of the conspiracy, but was certain it existed.

${ }^{23}$ W[illiam] E[lderton], "A ballat intitled Northormberland newes" (London: Thomas Purfoote, 1569-70). 


\section{REFERENCES}

\section{Primary Sources}

Abbot, Robert. A Mirrour of Popish Subtilties. London: Thomas Creede for Thomas Woodcocke, 1594. STC 52; EEBr 163.

Allen, William, Cardinal. Defence of English Catholics. [with Execut. of Just.] Ithica: Cornell UP, 1965.

Bale, John. The Pagent of Popes. [London: Thomas Marsh], 1574, tran. with additions by J[ohn] S[tudley]. STC 1304; EEBr 375.

Barthlet, John. The pedegrewe of heretiques. London: Henry Denham, 1566. STC 1534; $\mathrm{EEBr} 486$.

Baxter, John. A Toile for Two-legged Foxes. London: Felix Kyngston, 1600. STC 1596; $\mathrm{EEBr} 486$.

Bell, Thomas. The Anatomie of Popish Tyrannie. London: John Harrison, 1603. STC 1814; $\mathrm{EEBr} 662$.

Bunny, Francis. Truth and Falsehood. London: Valentine Sims, 1595. STC 4102; EEBr 487.

Burton, Robert. The Anatomy of Melancholy. New York: Tudor Publishing Co., 1927, edited by Floyd Dell and Paul Jordan-Smith.

Cambell, Lily B., editor. The Mirror for Magistrates. New York: Barnes and Nobel, Inc., 1960, reprint of CUP, 1938. Compilation of all editions.

Cecil, William. The Execution of Justice in England. Ithica: Cornell UP, 1965. 1584 edition edited by Robert M. Kingdon. STC 4901-4902. Some think this was by Thomas Norton.

- Letter to Mendoza. London: Thomas Vautrollier for Richard Fielde, 1588. STC 15412; EEBr 262.

. Salutem in Christo. London: n.p., 1571. STC 11504; EEBr 567. By "R. G." attributed to Cecil.

- A True Report of Sundry Horrible Conspiracies. London: Charles Yesweirt, 1594. STC 7603; EEBr 381. Name missing from title page. 
Collier, J. Payne, editor. Broadside Blackletter Ballads. New York: Burt Franklin, 1968; reprint of 1868 .

E[lderton], W[illiam]. "A ballat intitled Northomberland newes." London: Thomas Purfoote, 1569-70. STC 7554; EEBr 381.

Evans, Lewys. The Hatefull Hypocrisie. London: Thomas Purfoote, 1570. STC 10591; $\mathrm{EEBr} 343$.

Fenner, Dudley. An answer unto the confutation of John Nichols. London: John Wolfe for John Harrison and Thomas Man, 1583. STC 10764; EEBr 507.

Fielde, John. A Caveat for Parsons Howlet. London: Robert Waldegrave, 1581. STC 10844; EEBr 507.

Foxe, John. The Acts and Monuments of John Foxe. London: R. B. Seeley and W. Burnside, 1841. Edited in 8 volumes by S. E. Cattley; compilation of several editions.

Lewkenor, Sir Lewis. A Discourse of the Usage of the English Fugitives by the Spaniard. London: Thomas Scarlet for John Drawater, 1595. STC 15562; EEBr 443.

. The Estate of English Fugitives. London: [Scarlet?] for John Drawater, 1595. STC 15564; EEBr 263.

Lightfoot, William. The Complaint of England. London: John Wolfe, 1587. STC 15595; EEBr 263.

Lupton, Thomas. A Persuasion from Papistrie. London: Henry Bynneman, 1581. STC 16950; $\mathrm{EEBr} 408$.

Marten, Anthony. An Exhortation. London: John Windet, 1588. STC 17489a; 674.

Moxon, Joseph. Mechanick Exercises on the Whole Art of Printing. London: OUP, 1962; 1st edition 1683-4. Edited by Herbert Davis and Harry Carter.

Munday, Anthony. An advertisement and defense for Truth. [London]: n.p., 1581. STC 18259; $\mathrm{EEBr} 324$.

- A breefe Answer made unto two seditious Pamphlets. London: John Charlewood, 1582. STC 18262; EEBr 324.

A Discoverie of Edmund Campion. London: Edwarde White, 1582. STC 18270; EEBr 324.

. The English Romayne Life. [London: John Charlewood] for Nicholas Ling, [1582]. STC 18272; EEBr 426. 
Murriell, Christopher. An answer unto the Catholiques supplication. London: R. Reade for Francis Burton, 1603.

Nash, Thomas. Pierce Penilese. London: Richard Jones, 1592. STC 18371; EEBr 1636.

Nichols, John. A declaration of the recantation of John Nichols. London: Christopher Barker, 1581. STC 18533; EEBr 325. $\mathrm{EEBr} 325$. . John Nichols pilgrimage. London: Thomas Dawson, 1581. STC 18534;

Nichols, Josias. The plea of the innocent. n.c.: n.p., 1602. STC 18542; EEBr 1179.

Norton, Thomas. A Bull granted by the Pope. London: John Day, 1570. STC 18678; $\mathrm{EEBr} 1283$.

. An addition declaratorie to the Bulles. [London: John Day, 1570]/ STC 1867a; EEBr 1283.

. A declaration of the favourable dealing. [London]: n.p., 1583. STC 4901; EEBr 190. Also attributed to Cecil, and is so listed in the STC.

Perkins, William. A Reformed Catholike. Cambridge: John Legat, 1598. STC 19736; $\mathrm{EEBr} 388$.

Southwell, Robert, S. J. An humble supplication to Her Majestie. n.c.: n.p., 1595. STC 7586; ERL 123; Alison and Rodgers 784.

Whetstone, George. The Censure of a loyall Subject. London: Richard Jones, 1587. STC 15334; EEBR 371.

White, Peter. An answeare unto certaine crabbed questions. London: John Wolfe and Henry Kirkham, [1582]. STC 25401; EEBr 1469.

Willet, Andrew. A catholicon or remedie against the psuedo-catholike religion.

Cambridge: John Legat, 1602. STC 15673; EEBr 1469.

- Tetrastylon papisticum. [London]: Robert Robinson, 1593, for Thomas Mann. STC 25701; EEBr 1052.

"Willobie, M. Henry." Edited by "Hadrian Dorrell." Willobie His Avisia. London: John Windet, 1594; reprinted by New York: Barnes and Noble, 1966. With essay on the problem of authorship by G. B. Harrison. 
Aveling, J. C. H. The Handle and the Ax. London: Blond and Briggs, Ltd., 1976.

Barker, Nicholas. The Oxford University Press and the Spread of Learning. Oxford: The Clarendon Press, 1978.

Bayne, C. G. Anglo-Roman Relations: 1558-1565. Oxford: The Clarendon Press, 1913; 1968 reprint.

Bennett, H. S. English Books and Readers, 1475-1557. Cambridge: CUP, 1970, reprint of 2 nd edition.

. English Books and Readers, 1558-1603. Cambridge: CUP, 1965.

Billington, Ray Allen. The Protestant Crusade 1800-1860. New York: Macmillian, 1938; reprinted by Rinehart and Co., 1952.

Bindoff, S. T. Tudor England. Harmondsworth: Penguin Books, 1950; reprint 1980.

Blagden, Cyprian. The Stationers' Company Stanford: SUP, 1977; reprint of London: George Allen and Unwin, Ltd., 1960.

Bossy, John. The English Catholic Community: 1570-1850. New York: Oxford UP, 1976.

Bouwsma, William J. "Anxiety and the Formation of Early Modern Culture," in After the Reformation. n.c.: University of Pennsylvania P, 1980. Edited by Barbara C. Malamet.

Cheney, C. R. Handbook of Dates. London: Royal Historical Society, 1970.

Clair, Colin. A History of Printing in Britain. London: Cassell and Co. Ltd., 1965.

Clancy, Thomas. "English Catholics and the Papal Deposing Power: 1570-1640," Recusant History, Vol. 6, No. 3 (October 1961), pp. 114-140.

. "Papist--Protestant--Puritan: English Religious Taxonomy, 1565-1665," Recusant History, Vol. 13, No. 4 (October 1976), pp. 227-253.

Clifton, Robin. "The Popular Fear of Catholics During the English Revolution," Past and Present, No. 52 (August 1971), pp. 23-55.

Cressy, David. Literacy and the Social Order. Cambridge: CUP, 1980.

Cross, Claire. The Royal Supremacy in the Elizabethan Church. London: George Allen and Unwin Ltd., 1969. 
Drabble, John E. "Mary's Protestant Martyrs and Elizabeth's Catholic Trators in the Age of Catholic Emancipation," Church History, Vol. 51 (June 1982), No. 2, pp. 172-185.

Duff, Edward Gordon. The Printers, Stationers and Bookbinders of Westminster and London from 1476 to 1535. Oxford: OUP, 1906.

Elton, G. R. Policy and Police. Cambridge: CUP, 1972. . The Tudor Constitution. Cambridge: CUP, 1960; reprinted 1968.

Fletcher, Anthony. Tudor Rebellions. Harlow, Essex: Longman Group Ltd., 1968, third edition, 1983.

Gee, Henry, and William John Hardy, editors. Documents Illustrative of English Church History. London and New York: Macmillian and Co., 1896.

Greg, W. W. Some Aspects and Problems of London Publishing. Oxford: The Clarendon Press, 1956.

Guy, J. A. The Court of Star Chamber and Its Records to the Reign of Elizabeth I. London: Her Majesty's Stationery Office, 1985.

Hale, J. P. "Sixteenth Century Explanations of War and Violence," Past and Present, No. 51 (May 1971), pp. 3-26.

Haller, William. The Elect Nation. New York: Harper \& Row, 1963.

Handover, P. M. Printing in London 1476 to Modern Times. Cambridge: Harvard UP, 1960.

Harris, P. R. "William Fleetwood, Recorder of the City," Recusant History, Vol. 7, No. 3 (October 1963), pp. 106-122.

Haugaard, William P. Elizabeth and the English Reformation. Cambridge: CUP, 1968.

Hofstadter, Richard. The Paranoid Style in American Politics, and Other Essays. New York: Alfred A. Knopf, 1965.

Hoppee, H. P. "John Wolfe," The Library, 4th Series, Vol. XIV, iii (December 1933), pp. 241-289.

Krummel, D. W. English Music Printing 1553-1700. London: The Biographical Society, 1975.

Lake, Peter. "The Significance of the Elizabethan Identification of the Pope as Antichrist," Journal of Ecclesiastical History, Vol. 31, No. 2 (April 1980). 
Levy, F. J. "How Information Spread Among the Gentry, 1550-1640," The Journal of British Studies, Vol. XXI, No. 2 (Spring 1982), pp. 11-34.

Loach, Jennifer. "The Marian Establishment and the Printing Press," English Historical Review, Vol. CI (January 1986), pp. 135-148.

Loades, David. The Tudor Court. Totowa, NJ: Barnes and Noble Books, 1987.

. "The Theory and Practice of Censorship in Sixteenth Century England," Transactions of the Royal Historical Society, 5th series, Vol. 24 (1974), pp. 414-457.

McGrath, Patrick. Papists and Puritans. London: Blandford Press, 1967.

Mac Lure, Millar. The Paul's Cross Sermons: 1534-1642. Toronto, UTP, 1958.

Manning, Roger B. "The Origins of the Doctrine of Sedition," Albion, Vol. 12, No. 2 (Summer 1980).

Meyer, Arnold Oskar, translated by McKee. England and the Catholic Church Under Elizabeth I. London: Routledge and K. Paul, 1967.

Milward, Peter. Religious Controversies of the Elizabethan Age: A Survey of Printed Sources. Lincoln and London: U Nebraska P, 1977.

Neale, J. E. The Elizabethan House of Commons. New Haven: Yale UP, 1950.

Oehling, Richard A Late Elizabethan Government Treatment of Religious NonConformity, 1589-1603. Rutgers unpublished Ph.D. dissertation, 1969.

Pantzer, Katherine F. "Printing the English Statutes: 1484-1640," in Books and Society in History. New York and London: R. R. Bowker Co., 1983, edited by Kenneth E. Carpenter.

Pickrill, D. A. Ministers of the Crown. London: Routledge and Kegan Paul, 1981.

Plant, Marjorie. The English Book Trade. London: Allen and Unwin, 1965.

Pollard, Graham. "The English Market for Printed Books," Publishing History, Vol. IV (1978), pp. 7-48.

Prothero, G. W., editor. Select Statues and Other Constitutional Documents. Oxford: The Clarendon Press, 1894; 4th edition 1913; reprint 1949.

Read, Conyers. Mr. Secretary Cecil and Queen Elizabeth. London: Jonathan Cape, 1955. 
1960.

. Lord Burghley and Queen Elizabeth. New York: Alfred A. Knopf,

. "William Cecil and Elizabethan Public Relations," in Elizabethan Government and Society. London: The Athlone Press, 1961. Edited by Bindoff, Hurstfield, and Williams.

Reynolds, E. E. Campion and Parsons. London: Sheed and Ward, 1980.

Russell, Conrad. "Arguments for Religious Unity in England, 1530-1650," Journal of Ecclesiastical History, Vol. 18, No. 2 (October 1967), pp. 201-226.

. The Crisis of Parliaments. London and New York: OUP, 1977.

Siebert, Frederick S. Freedom of the Press in England. Urbana: U of Illinois P, 1952.

Slavin, Arthur J. The Tudor Age and Beyond. Malabar, FL: Robert E. Krieger Publishing Co., 1987.

Smith, Lacey Baldwin. Treason in Tudor England. Princeton: PUP, 1986.

Thomas, Donald. A Long Time Burning. London: Routledge and Kegan Paul, 1969.

Tillyard, E. M. W. The Elizabethan World Picture. New York: Random House, [1960].

Wiener, Carol Z. "The Beleaguered Isle," Past and Present, Vol. 51 (May 1971), pp. 27-51.

- Popular Anti-Catholicism in England, 1559-1618. Harvard unpublished Ph.D. thesis, 1968.

Willoughby, Edwin Eliot. A Printer of Shakespeare. New York: Haslell House Publishers, Ltd., 1934; reprinted 1970.

Woodfield, Denis B. Surreptitious Printing in England, 1550-1640. New York: Biographical Society of America, 1973.

Youings, Joyce. Sixteenth-Century England. Harmondsworth: Penguin Books, 1984. 


\section{APPENDIX: \\ SOME ACTS REGULATING "PUBLISHING" \\ $1530-1588$}

1530 Prohibition of Bulls from Rome (12 September)

1534 Treason Act (26 Henry VIII, c. 13)

1536 Seditious Rumors and Unlawful Assembly (29? October) ${ }^{1}$

1539 Statute of Proclamations (31 Henry VIII, c. 8)

1546 Prohibition of Heretical Books (8 July)

1547 Edward's First Treason Act (1 Ed. VI, c. 12)

Seditious Rumors (24 May)

1549 Against Rumors of Military Defeat (29 April)

Arrest of Rumor Mongers (8 July)

Arrest of Those Spreading Seditious Rumors (30 October)

1552 Second Treason Act (5 and 6 Ed. VI, c. 11)

1553 Mary's First Treason Act (1 Mary, St. 1, c. 1)

Suppression of Seditious Rumors (28 July)

Prohibition of Unlicensed Plays and Printing (18 August)

1554 Second Treason Act (1 and 2 Philip and Mary, c. 10)

1555 Against Heretical Books (13 June)

1557 Company of Stationers Chartered (3 and 4, P. and M., pt 10, m 46)

1558 Suppression of Seditious Rumors

Martial Law Against Heretical Books (5 June)

1559 Elizabeth's First Treason Act (1 Eliz., c. 5)

1562 Second Commission 
1566 Reformation of the Printing of Books (19 June)

1569 Against Seditious Books (1 March)

1570 Against Books, Bulls, and Writings (1 July)

Against Seditious Persons and Books (14 November)

1571 Second Treason Act (13 Eliz. c. 1)

Against the Importation and Execution of Bulls (13 Eliz. 2).

1572 Third Commission

1573 Importation of Sed. Books [Catholic] (28 September)

Against Admonition to the Parliament (11 June)

1576 Against Libels and Rumors (16 March)

Fourth Commission

1581 Against Seditious Words and Rumors (23 Eliz. c. 2)

1583 Against Seditious Books [Puritan] (30 June)

1584 Fifth Commission

1585 Surety of the Royal Person (27 Eliz. c. 1)

1586 Star Chamber Decree on Printing (23 June)

1588 Martial Law--Possessors of Bulls, Books, Phamps. (1 July) 